\title{
Reptiles as a Model System to Study Heart Development
}

\author{
Bjarke Jensen and Vincent M. Christoffels \\ Department of Medical Biology, Amsterdam Cardiovascular Sciences, University of Amsterdam, Amsterdam \\ UMC 1105AZ, Amsterdam, The Netherlands \\ Correspondence: b.jensen@amsterdamumc.nl
}

\begin{abstract}
A chambered heart is common to all vertebrates, but reptiles show unparalleled variation in ventricular septation, ranging from almost absent in tuataras to full in crocodilians. Because mammals and birds evolved independently from reptile lineages, studies on reptile development may yield insight into the evolution and development of the full ventricular septum. Compared with reptiles, mammals and birds have evolved several other adaptations, including compact chamber walls and a specialized conduction system. These adaptations appear to have evolved from precursor structures that can be studied in present-day reptiles. The increase in the number of studies on reptile heart development has been greatly facilitated by sequencing of several genomes and the availability of good staging systems. Here, we place reptiles in their phylogenetic context with a focus on features that are primitive when compared with the homologous features of mammals. Further, an outline of major developmental events is given, and variation between reptile species is discussed.
\end{abstract}

Reptiles evolved from amphibians and gave Rrise to mammals and birds independently (Fig. 1; Warren et al. 2008; Zhang et al. 2014). This central position in the phylogeny of landliving vertebrates makes reptiles very attractive in evolutionary studies; they feature prominently in comparative anatomical and physiological works (Randall et al. 2002; Kardong 2006). Studies on (heart) development of reptiles, however, are few when compared with studies on development of zebrafish, Xenopus frogs, chicken, and mouse (Koshiba-Takeuchi et al. 2009; Jensen et al. 2013a; Poelmann et al. 2017). The paucity of studies likely reflects that reptiles have some internal development (until the beginning of heart chamber development in many species, see below) and they have less anatomical and physiological properties in common with human as compared with other animal models such as mouse. From the perspective of heart development, reptiles are very attractive nonetheless, because they show more variation in ventricular septation than any other vertebrate class and they may suffer from ventricular septal defects (Brockman and Kennedy 1962; Sklansky et al. 2001; Jensen and Wang 2009). In human, congenital defects to the ventricular septum can have profound impact on ventricular function (Hoffman and Kaplan 2002). Nevertheless, much remains unknown of the development of the ventricular septum (Bruneau 2008; Bellmann et al. 2016). Any line of evidence

Editors: Benoit G. Bruneau and Paul R. Riley

Additional Perspectives on Heart Development and Disease available at www.cshperspectives.org

Copyright (C) 2020 Cold Spring Harbor Laboratory Press; all rights reserved; doi: 10.1101/cshperspect.a037226

Cite this article as Cold Spring Harb Perspect Biol 2020;12:a037226 


\section{B. Jensen and V.M. Christoffels}
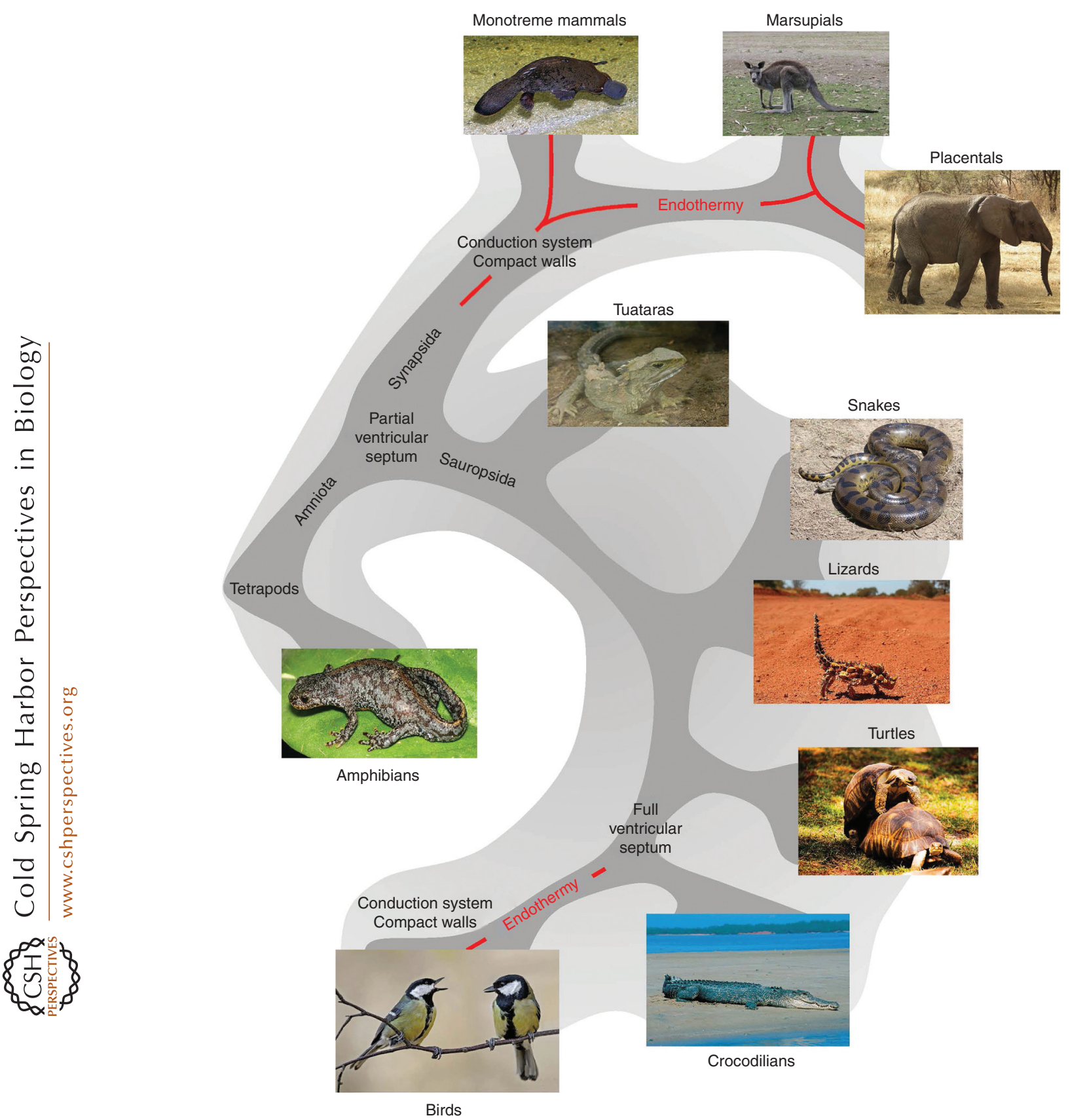

Figure 1. Phylogeny of extant tetrapod vertebrates. Amniotes evolved from amphibians. These stem amniotes are likely to have been ectothermic. Their ventricles are likely to have had a partial septum, like the muscular ridge of extant reptiles, because this septum arise from the gestational incorporation of the outflow tract, which happens in all amniotes except amphibians. From these stem amniotes evolved the synapsid lineage, which gave rise to mammals, and the sauropsid lineage, which gave rise to reptiles (ectothermic sauropsids), and later birds (endothermic sauropsids). Endothermy evolved independently in mammals and birds, which is reflected in the convergent evolution of compact chamber walls and specialized conduction systems. The phylogenetic tree is based on Green et al. (2014). (All photos are reprinted from Wikipedia courtesy of Creative Commons Licensing.) 
that can improve our understanding of septation is, therefore, important with respect to modeling human septal defects.

\section{WHAT ARE REPTILES?}

The extant reptiles comprise some 10,000 species that are grouped into the crocodilians, turtles, lizards, and snakes (Squamata), and tuataras (lizard-like nonlizards) (Fig. 1; Kardong 2006; Green et al. 2014). From the point of view of cladistics, "reptiles" also comprise birds (Aves) in the clade Sauropsida (Fig. 1; Kardong 2006; Zhang et al. 2014). Birds, however, are endothermic, or warm-blooded, as they have much higher metabolic rates than reptiles (Geiser et al. 2017) and their hearts have multiple anatomical and physiological specializations (Smith et al. 2000; Kroneman et al. 2019). Herein, "reptiles" will be used to mean ectothermic sauropsids. Reptiles and their descendant mammals and birds can lay their eggs out of the water, in contrast to amphibians, because of the amniotic membrane and a sturdy egg shell (Kardong 2006) (only monotreme mammals lay eggs, and in some reptiles all development of the egg occurs inside the female, a phenomenon known as ovovivoparity). In the heart, the most pronounced difference between amphibians and reptiles is that the myocardial outflow tract, or conus, persists in the formed hearts of amphibians, whereas it is incorporated into the ventricle of reptiles, birds, and mammals during development (Greil 1903; Jensen et al. 2013a). The incorporation of the myocardial outflow tract into the ventricle is associated with the formation of the partial ventricular septum known as the muscular ridge, from which most of the ventral part of the full ventricular septum seems to have evolved (Greil 1903; Jensen et al. 2013a; Poelmann et al. 2014).

Reptiles are poikilothermic ectotherms, meaning that their body temperature follows that of the environment (Tattersall 2016). In contrast, almost all mammals and birds are homeothermic endotherms, meaning that their body temperature is constant across a temperature range (the thermoneutral zone). The metabolic rate of reptiles is then greatly influenced by the environmental temperature, level of activity, reproductive cycle, state of digestion, etc. (Randall et al. 2002). Metabolic rate relies on adequate blood perfusion of the tissues (Crossley et al. 2016). Accordingly, cardiac output, the volume of blood pumped by the heart per minute, is tightly related to metabolic rate. Because change in heart rate is the major determinant of cardiac output in reptiles, like it is in mammals and birds, heart rate is a proxy measure for metabolic rate (Lillywhite et al. 1999; Du et al. 2010) and, in effect, rate of development ( $\mathrm{Du}$ et al. 2011). Nevertheless, even if the body temperature of reptiles is raised to $35^{\circ} \mathrm{C}-40^{\circ} \mathrm{C}$, their metabolic rate will still be some 5-10 times lower than that of equally warm mammals and birds (Else and Hulbert 1987; Randall et al. 2002).

\section{WHY STUDY REPTILES?}

In what is now known as the August Krogh principle, it is stated that for "a large number of problems, there will be some animal of choice or a few such animals on which it can be most conveniently studied" (Krogh 1929). Convenience can be a favorable combination of the ease of experimentation and the presence of intriguing biological attributes. Among the intriguing biological attributes of reptiles, we find the ability to instantaneously lose and regenerate a large body part such as the tail in geckos (Sanggaard et al. 2012), to digest huge meals during which metabolic rate increases above that of exercise (Secor and Diamond 1998), and to produce potent venom (Vonk et al. 2013). Concerning the heart, within reptiles there is an unparalleled variation in ventricular septation (Jensen et al. 2014). For example, there are two instances where septation has evolved to such an extent that the ventricle is functionally separated into a low-pressure right side and a high-pressure left side, namely, in monitor lizards and python snakes (Burggren and Johansen 1982; Wang et al. 2003). In these animals, there is a small luminal continuity between the left and right side (which closes in systole) and some mixing of bloodstreams, or shunting, is inevitable (Ishimatsu et al. 1988; Jensen et al. 2010). Although the variation in 
ventricular septation makes the hearts of reptiles particularly interesting, reptilian heart development offers insight into the evolution of a number of important processes. For instance, the pattern of electrical activation of the chambers, the cardiac conduction system, atrial septation, the atrioventricular valve apparatus of fourchambered hearts, chamber walls of predominantly compact myocardium, and outflow tract septation.

\section{CHAMBERS OF REPTILE HEARTS}

The formed reptile heart has two atria and one ventricle (Goodrich 1930; Benninghoff 1933; Holmes 1975; Webb 1979). Only crocodilians have a full ventricular septum and two ventricles (Webb 1979; Farrell et al. 1998; Cook et al. 2017). An additional chamber is found upstream of the right atrium, namely, the sinus venosus (SV) (Keith and Flack 1907). The electrocardiogram (ECG) of reptiles consequently reveals three distinct chamber activations; the SV wave followed by a sinuatrial delay, $\mathrm{P}$ wave (atria), followed by an atrioventricular delay, and then the QRS complex followed by the T wave (Mullen 1967; Valentinuzzi and Hoff 1972). Facilitated by the sinuatrial delay in electrical activation, the SV activates and contracts before the atria and thus functions as a separate chamber (Jensen et al. 2017b). In mammals, the embryo develops an SV, which later becomes the caval vein myocardium that activates together with the atrial myocardium (Spach et al. 1972; Opthof 1988; Steding et al. 1990; Faber et al. 2019). The walls of the atrial and ventricular chambers of reptiles are readily distinguishable from the chamber walls of mammals and birds by their very extensive layer of fine trabecular muscle (Jensen et al. 2016a, 2018; Boukens et al. 2019; Kroneman et al. 2019). Because the chamber walls are largely trabecular, much of the myocardium can be nourished by the blood of the chamber lumens (Ostadal et al. 1999; Sedmera and Ostadal 2012). The luminal nourishment is likely the cause of the significant tolerance of reptiles to ischemia arising from coronary artery ligation (Kohmoto et al. 1997; Hagensen et al. 2008).

\section{VESSELS OF REPTILE HEARTS}

The pulmonary circulation converges to a single pulmonary vein connecting to the left atrium (Jensen et al. 2014). There is little or no myocardium in the pulmonary venous walls (Joyce et al. 2019). Most mammals and all birds have myocardium in the intrapericardial part of the pulmonary veins (Nathan and Gloobe 1970; Rowlatt 1990; Kroneman et al. 2019). In reptiles, there are three caval veins connected to the right atrium as is the case in most tetrapods (Benninghoff 1933; Farrell et al. 1998). These veins, however, have myocardial walls (extending to the pericardial reflection) and are also referred to as the SV (Jensen et al. 2017b). There is a single pulmonary artery and two aortas. Each of the three arteries is guarded by a bicuspid valve (Poelmann et al. 2017). The coronary circulation begins in the valvular sinuses of either aorta, or both aortas spreading throughout the entire heart and the coronary veins connect to the SV (Grant and Regnier 1926; MacKinnon and Heatwole 1981; Jensen et al. 2016b).

\section{VALVES OF REPTILE HEARTS}

The entry of the SV to the right atrium is regulated by the myocardial sinuatrial valve, which has two leaflets (Keith and Flack 1907; Faber et al. 2019). Between the atria and the ventricle(s), there is a single atrioventricular junction divided into left and right halves by the atrial septum (Benninghoff 1933; Webb 1979; Farrell et al. 1998). The atrial septum ends in a membranous parachute-shaped atrioventricular valve. It has free margins laterally and is attached to atrioventricular muscle dorsally and ventrally. Small cushions can be found opposite the free margins. Morphologically, the atrioventricular junction of (noncrocodilian) reptiles resembles a mammal atrioventricular junction with a very large membranous septal defect and with very poorly developed parietal leaflets. In crocodilians, the atrioventricular valve apparatus resembles that of birds and monotreme mammals (Van Mierop and Kutsche 1985b; Jensen et al. 2013a). 


\section{FUNCTION OF REPTILE HEARTS (VENTRICLES)}

The low metabolic rate of reptiles compared with mammals and birds is reflected in their heart rates, which are several-fold lower (Lillywhite et al. 1999; Boukens et al. 2019). Also, the ventricular stroke volume is smaller, under $1 \mathrm{~mL}$ $\times \mathrm{kg}^{-1}$ body weight, compared with the $\sim 1 \mathrm{~mL}$ $\times \mathrm{kg}^{-1}$ body weight in mammals and $1.4 \mathrm{~mL} \times$ $\mathrm{kg}^{-1}$ body weight in birds (Seymour and Blaylock 2000; Jensen et al. 2014). Further, mean arterial systemic blood pressure is low, often some 30-40 mmHg (Burggren et al. 1998; Jensen et al. 2014), much lower than the $\sim 90$ $\mathrm{mmHg}$ observed in most mammals (Poulsen et al. 2018). Therefore, a reptile ventricle performs less work per beat and the heart weight to body weight ratio is approximately one-half that of mammals, or one-quarter percent of body weight (Seymour 1987; Seymour and Blaylock 2000; Jensen et al. 2014). Hence, the work performed per beat per gram ventricle is approximately the same in ectotherms and endotherms (Hillman and Hedrick 2015). Because the (noncrocodilian) ventricle does not have a full septum, blood will preferentially be ejected to the pulmonary circulation or the systemic circulation dependent on the relative resistance of the two circulations (Hicks and Wang 2012; Joyce et al. 2016). The relative resistances are strongly influenced by the autonomic nervous system (Hicks and Wang 2012; Leite et al. 2013; Taylor et al. 2014).

\section{THE NONCROCODILIAN REPTILE HEART LIKELY RESEMBLES THE ANCESTRAL MAMMAL HEART}

That reptile hearts share some features with the (developing) hearts of mammals provides rationale for use of reptiles as a model organism of heart development. Within comparative anatomy, shared features have been recognized over many centuries (Gegenbaur 1878; Keith and Flack 1907; Goodrich 1930; Benninghoff 1933; Harvey 1995). Before homeothermic endothermy evolved within the mammal lineage, these protomammals likely had a heart quite like those of squamate reptiles (Jensen et al. 2019). This conjecture is based on four observations. First, the sinuatrial valve is found in amphibians, reptiles, birds, and monotremes (Benninghoff 1933; Jensen et al. 2017b; Kroneman et al. 2019). Second, amphibians, reptiles, birds, monotremes, and marsupials develop their atrial septum from the primary septum only (Röse 1889, 1890; Runciman et al. 1995; Jensen et al. 2019). Third, only in the development of reptiles, birds, and mammals will the myocardial outflow tract incorporate to the ventricle (Greil 1903; Goor et al. 1972; de la Cruz et al. 1977; Zaffran et al. 2004; Rana et al. 2007; Grimes and Kirby 2009). Fourth, the atrial and ventricular chambers are much more trabecular, or spongy, in ectotherms (Benninghoff 1933; Van Mierop and Kutsche 1984; Boukens et al. 2019). All four features only occur in reptile hearts.

\section{REPTILE GENOMES}

Sequencing of genomes allows for the direct comparison of DNA of different species (Tollis et al. 2014) and it facilitates, for instance, the development of messenger RNA (mRNA) probes for the detection of transcripts by in situ hybridization (Koshiba-Takeuchi et al. 2009; Jensen et al. 2012; Poelmann et al. 2014) and the analysis of evolutionary conservation of gene regulatory elements (Kvon et al. 2016). Several genomes have been sequenced of reptiles that, from the perspective of variation in cardiac (mainly ventricular) anatomy and physiology, represent typical or specialized features. This includes the green anole (Alföldi et al. 2011) (typical lizard ventricle [Jensen et al. 2014]), the central bearded dragon (Georges et al. 2015) (typical lizard ventricle [Hanemaaijer et al. 2019]), the garter snake (Perry et al. 2018) (typical snake ventricle [Jensen et al. 2014]), the painted turtle (Badenhorst et al. 2015) (typical turtle ventricle, personal observation), the Burmese python (Castoe et al. 2011; Duan et al. 2017) (functionally divided ventricle, unique trait of pythons among snakes [Jensen et al. 2014]), the Komodo dragon (Lind et al. 2019) (functionally divided ventricle, unique trait of monitor lizards among lizards [Jensen et al. 2014]), and the American 
alligator (Green et al. 2014) (fully divided ventricle [Jensen et al. 2014]).

\section{STAGING OF DEVELOPING REPTILES}

Organs develop in different rates between species (de Bakker et al. 2016) and although the early development of vertebrate hearts can be quite similar, the timing of the completion of the primary atrial septum, for example, may differ between species (Sissman 1970). A standardized staging of the developmental stages is then important. The early stages of reptile (heart) development can be staged much like chicken is staged (Hamburger and Hamilton 1992; Poelmann et al. 2017). Ontogeny, however, does not fully recapitulate phylogeny (Richardson 1999) and staging systems have been developed for multiple species of reptiles, including for crocodilians (Ferguson 1985), the green anole (Sanger et al. 2008), the common garter snake (Zehr 1962), the African rock python (Boughner et al. 2007), the African house snake (Boback et al. 2012), the striped sand snake (Khannoon and Zahradnicek 2017), the spiny softshell turtle (Greenbaum and Carr 2002), the common snapping turtle (Yntema 1968), the redbellied short-necked turtle (Werneburg et al. 2009), the leopard gecko (Wise et al. 2009), and the mangrove monitor (Gregorovicova et al. 2012). In many species of lizards and snakes, there is substantial internal development before the eggs are laid. Stages younger than equivalents of Hamburger-Hamilton stage 15 of chicken (initial chamber development) have to be removed from the pregnant females (Zehr 1962). Embryos of crocodilians have between 9 and 20 pairs of somites when the eggs are laid (Ferguson 1985), by which measure they equal chicken HamburgerHamilton stage 10-13 (initial looping of the heart tube). The eggs of the common snapping turtle and the spotted turtle are laid when the embryos are very immature and most stages of heart development can be studied (Agassiz 1857; Yntema 1968). In the spiny softshell turtle and red-bellied short-necked turtle, the eggs are laid around the time of looping of the heart tube (Greenbaum and Carr 2002; Werneburg et al. 2009).

\section{REPTILE HEART DEVELOPMENT}

The early embryonic reptile heart is a tube that subsequently loops, like it does in most vertebrates (Agassiz 1857; Greil 1903; Ferguson 1985; Crossley and Burggren 2009; Bertens et al. 2010; Jensen et al. 2013a; Manner and Yelbuz 2019). The atrial and ventricular compartment then balloon out from the heart tube and the formation of trabeculae begin simultaneously (Fig. 2A; Moorman and Christoffels 2003). Two nonchamber parts, the atrioventricular canal and the myocardial outflow tract, are proportionally large (Fig. 2A). The development of the SV is revealed as myocardialization of the intrapericardial walls of the cardinal veins (Jensen et al. 2017b). Total myocardial mass increases throughout development because the ventricular and atrial compartments grow rapidly (Fig. $2 \mathrm{~B})$. In the formed heart, $\sim 80 \%$ of the mass is ventricular and $\sim 15 \%$ of the mass is atrial, which resembles the situation in many other vertebrates (Jensen et al. 2013a). The atrioventricular canal and the myocardial outflow tract, in contrast, are proportionally smaller over time because of low levels of proliferation (Fig. 2B; Jensen et al. 2012, 2013a). Further, the myocardial outflow tract becomes incorporated to the ventricle whereby it comes much shorter (Greil 1903; Bertens et al. 2010; Jensen et al. 2013a). In mammals and birds, similar developmental changes happen to the outflow tract (Goor et al. 1972; de la Cruz et al. 1977; Zaffran et al. 2004; Rana et al. 2007; Grimes and Kirby 2009).

Heart development in vertebrates rely on a core network of transcription factors that is evolutionarily conserved (Olson 2006; Kokubo et al. 2010; Bakkers 2011; Kelly et al. 2014; Diogo et al. 2015; Poelmann and Gittenberger-de Groot 2019). Transcription factors such as Tbx20, $T b \times 5$, and $N k \times 2.5$ are required for the formation of chambers in mouse (Bruneau et al. 1999; Kraus et al. 2001; Stennard et al. 2003) and are broadly expressed in the heart of reptiles (Fig. 3; Jensen et al. 2017b). Genes that are chamber specific in mammals, such as Nppa, Gja5, and Bmp10, are also restricted to chambers in reptiles (Koshiba-Takeuchi et al. 2009; Jensen et al. 2018). The formation of junctions, such as the 
A

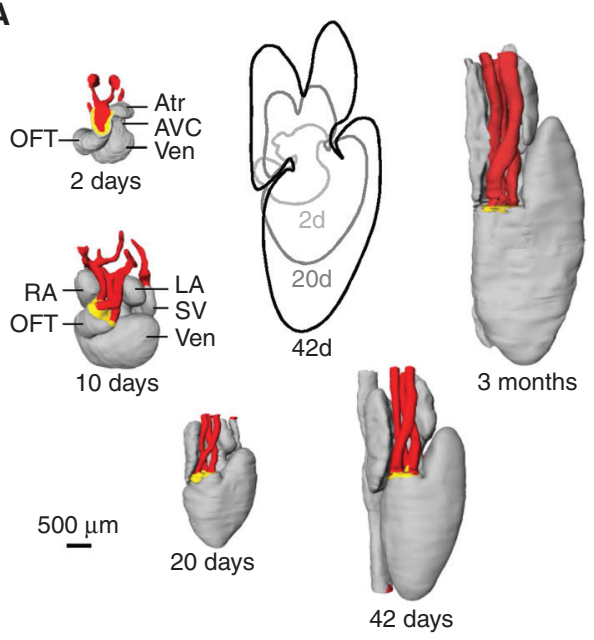

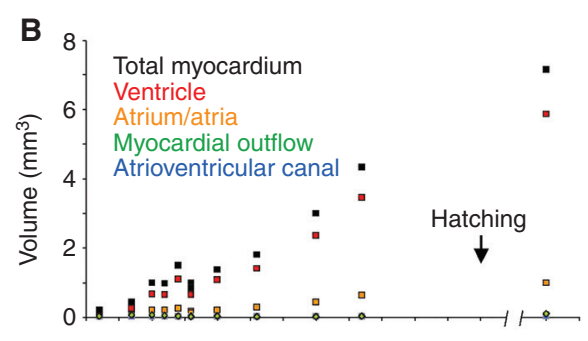

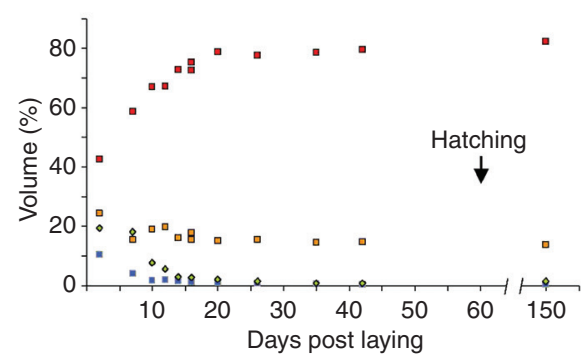

C
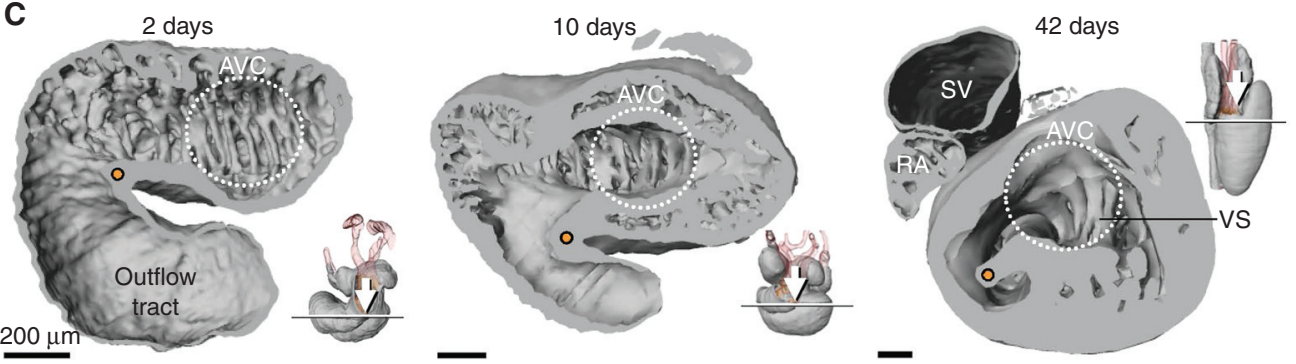

Figure 2. Morphological heart development of the corn snake. (A) At 2 days postoviposition, the heart tube has just begun to develop the common atrium (Atr) and the single ventricle (Ven). The atrioventricular canal (AVC) and the myocardial outflow tract (OFT) are proportionally large compared with later stages. By 10 days postoviposition, the left and right atrium can be seen (LA and RA, respectively), the ventricle is proportionally quite large, and the myocardial OFT is substantially shorter (because of it being incorporated into the ventricle). By 20 days postoviposition, the proportions of the heart are almost mature. $(B)$ The volumetric and proportional changes of the major compartments of the corn snake heart in development. By 20 days postoviposition, the heart still has to grow much more (upper graph), but the proportions are almost the same as those of older hearts. (C) Internal morphology of the developing ventricle, showing the relation between the AVC and the bulboventricular fold (orange dot, 2 and 10 days) and later the muscular ridge (orange dot, 42 days). Notice that it is only in late stages (42 days) that some of the ventricular trabeculae (vertical septum [VS]) are much closer to the AVC than the neighboring trabeculae. (SV) sinus venosus, (d) days. (All images in Fig. 2 are reprinted from Jensen et al. 2013a under the terms of the Creative Commons Attribution License for open-access articles.)

atrioventricular junction, relies on repression of the chamber program mediated by transcription factors such as $T b \times 2$ and $T b \times 3$ and growth factors such as Bmp2 (Yamada et al. 2000; Habets et al. 2002), which are also expressed in reptile hearts (Jensen et al. 2012). Figure 3 shows key elements of this network, the genes of which have been investigated in reptiles (text in red). The sinuatrial junction, which harbors the dom- inant pacemaker, expresses $T b \times 3$ and Bmp2 together with Isl1, a transcription factor that acts upstream of Tbx3 (Hoffmann et al. 2013; Vedantham et al. 2015; Burkhard et al. 2017; Jensen et al. 2017b; van Eif et al. 2018). Whereas Isl1 is expressed in a ring-like domain in reptiles and fish (Tessadori et al. 2012; Jensen et al. 2017b), it is confined to a small subset of the sinuatrial junction in adult mammals and birds, which, 
B. Jensen and V.M. Christoffels
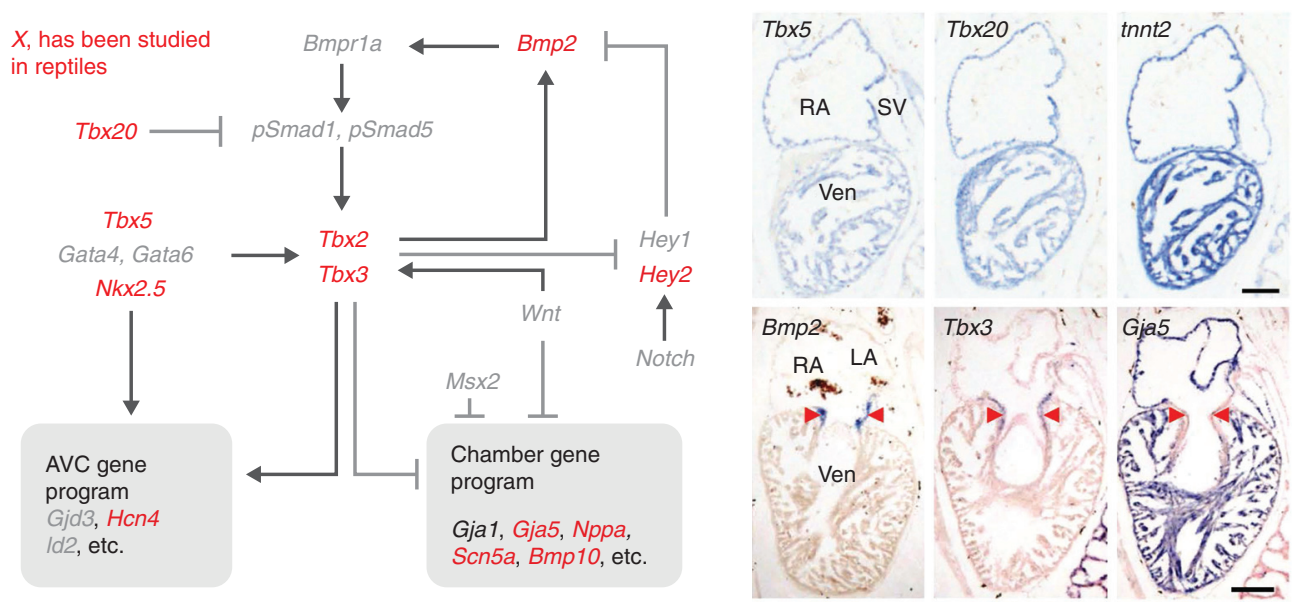

Figure 3. Molecular mechanisms that likely underlie reptile atrioventricular canal development. The genenetwork diagram is based on studies in mouse and shows the interaction of key genes of heart development. (Diagram adapted from van Eif et al. 2018.) Genes that have been studied in reptiles, principally by in situ hybridization and examples of which are shown on the right (in late gestational anole lizard hearts), are shown in red text. The images of the sections stained with in situ hybridization are created from data in Jensen et al. (2017b) (top row) and Jensen et al. (2012) (bottom row). (RA) right atrium, (SV) sinus venosus, (Ven) ventricle, (LA) left atrium. Scale bars, $100 \mu \mathrm{m}$.

at least in birds, has a highly variable anatomy (Kroneman et al. 2019). One outcome of chamber repression is low expression levels of gap junction proteins such as Gja5 and ion channels such as $\operatorname{Scn} 5 a$, both of which promote fast electrical activation (Delorme et al. 1995; Remme et al. 2009; Park and Fishman 2017), and these transcripts are not detected in the atrioventricular canal of reptiles (Jensen et al. 2012, 2017b, 2018). In contrast, these genes are enriched in the chambers, including the SV. This patterning of the heart imposes the electrical conduction properties that are revealed by the ECG (Boukens and Christoffels 2012), namely, fast activation of the chambers (SV, P, and QRS defections) and slow propagation in the chamber junctions (SV-P and PR delays).

In the atrioventricular canal, valve formation initiates from a dorsal and a ventral cushion and two much smaller cushions laterally (Greil 1903; Bertens et al. 2010; Jensen et al. 2013a). Before the completion of the atrial septum, the dorsal and ventral cushions will have merged. They will give rise to the parachute-like atrioventricular valve. Only in crocodilians, which have a full ventricular septum, will the lateral cushions give rise to significant parietal leaflets (Van Mierop and Kutsche 1985b; Cook et al. 2017). In crocodilians, birds, and mammals, the left and right atrioventricular junction have a similar offset and they all develop a membranous septum (Greil 1903; Shaner 1962; Cook et al. 2017). In the American alligator, the membranous septum acquires some myocardium and in birds the membranous septum is completely myocardialized (Jensen et al. 2018; Kroneman et al. 2019).

Although the chamber walls of reptiles are highly trabecular, the reptile ventricle has a thin outer layer of compact muscle that expresses Hey 2 and thus resembles the compact wall of the embryonic mouse heart (Koibuchi and Chin 2007; Stefanovic et al. 2014; Jensen et al. 2018). In Hey 2 mutant mice, the trabecular marker Nppa becomes ectopically expressed in the compact wall (Koibuchi and Chin 2007). In the American alligator, the compact wall expresses Hey2, whereas Nppa is confined to the trabecular layer (Jensen et al. 2018). Additionally, the embryonic trabecular wall of both reptiles and mammals expresses Bmp10 (KoshibaTakeuchi et al. 2009) and Gja5 (Jensen et al. 
2012, 2018). The embryonic ventricular (and atrial) walls are highly similar in reptiles and mammals; however, a key difference is whether the trabecular component is the most proliferative (leading to a reptile-like ventricle) or the compact component is the most proliferative (leading to a mammal-like ventricle) (Benninghoff 1933). The endocardium has important roles in regulating the contributions of the trabecular and compact components (D'Amato et al. 2016; Del Monte-Nieto et al. 2018). A recent systemic endothelial knockout of the chromatin remodeler Ino80 (Tie2Cre; Ino80 fl/fl) in mouse resulted in arguably the most reptile-like ventricular wall of any mouse model (Rhee et al. 2018). In the human heart, an excessive amount of trabecular myocardium allows for the diagnosis of noncompaction cardiomyopathy (Finsterer et al. 2017; Towbin and Jefferies 2017). This lesion has been considered a persistence of the evolutionarily old wall architecture (Angelini et al. 1999; Freedom et al. 2005). In contrasting to reptile trabeculae, the trabeculae during noncompaction do not express the trabecular markers CX40 (GJA5) and ANF (NPPA); the trabeculae are much fewer, orders of magnitude larger, and are vascularized by the coronary circulation (Jensen et al. 2016a, 2017a). Noncompaction may then be better defined as an aberration of normal mammalian cardiogenesis (Anderson et al. 2017).

\section{CARDIOMYOCYTES}

The cardiomyocytes are only $\sim 5-10 \mu \mathrm{m}$ wide in reptiles, other ectotherms, and birds. In mammals, the ventricular cardiomyocytes in particularly are much wider by comparison, $\sim 25 \mu \mathrm{m}$ (Hirakow 1970; Shiels and White 2008; Hirose et al. 2019). Simulations suggest that the electrical propagation through wider mammalian cardiomyocytes will be faster than through narrower reptile-like cardiomyocytes (Jensen et al. 2013b), consistent with the relatively fast chamber activations in mammals (Boukens et al. 2019). The size difference also yields a comparatively low surface-to-volume ratio in mammals, which is partly compensated for by a comparatively elaborate T-tubule system (Hirakow 1970;
Shiels and Galli 2014). In reptiles, the excitation-contraction coupling relies to a great extent on extracellular calcium ions, whereas in endotherms more calcium comes from intracellular stores (Bers 2002; Shiels and Galli 2014).

Cardiomyocyte proliferation underlies the formation of chambers from the embryonic heart tube (Sedmera et al. 2003). Cell-cycle activity and possibly proliferation of heart cells has been assessed by the detection of BrdU of pulselabeled nuclei, or by the use of antibodies against PCNA and pHH3 located in the nucleus (Riquelme et al. 2011; Jensen et al. 2013a; Jacyniak and Vickaryous 2018). That said, it is difficult to assign correctly a cell cycle-marker-positive nucleus to its native cytoplasm whereby cardiomyocyte identity can be established by the detection of sarcomeric proteins (Ang et al. 2010; Leone et al. 2015). In reptiles, this difficulty is likely aggravated by the small size of the cardiomyocytes.

\section{SEPTATION OF THE REPTILE HEART}

Septa develop in the atrium, ventricle, and outflow tract. Atrial septation is initially revealed as a ridge of mesenchyme in the atrial roof (Bertens et al. 2010; Jensen et al. 2019). The myocardial atrial septum then grows as a sheet from the roof and it carries on its leading edge the ridge of mesenchyme as a cap. This mesenchymal cap will eventually merge with the atrioventricular cushions and a dorsal protrusion of Isl1-expressing mesocardium, also known as the vestibular spine (Jensen et al. 2019). Although this merger of mesenchymal tissues closes the primary foramen, secondary perforations develop in the cranial part of the atrial septum that allow oxygen-rich blood to reach the left atrium. After hatching, the perforations are likely closed by growth of the surrounding tissues (myocardium, endocardium, fibroblasts). Reptiles do not form a secondary foramen or a secondary septum as seen in placental mammals (Röse 1889, 1890; Jensen et al. 2019). Nonetheless, many reptiles have a large aggregate of trabeculae in the same position as the crista dividens of the secondary septum, which becomes the superior rim of the oval fossa after birth (Jensen et al. 
2019). The inferior rim of the oval fossa consists of myocardialized mesenchyme of the mesenchymal cap and the dorsal mesenchymal protrusion. In reptiles, the dorsal mesenchymal protrusion has some capacity to myocardialize (myocardialization also happens in the contiguous sinus septum) and, at least in monitor lizards, the mesenchymal cap also develops myocardium (Jensen et al. 2019). The most pronounced difference between reptiles (and nonplacental mammals) and placental mammals with regard to the secondary septum, then, may be the extent of its growth.

The formed reptile ventricle may be viewed as having three partial septa, which only become apparent well after chamber formation has begun (Webb et al. 1971; Farrell et al. 1998; Jensen et al. 2014). One septum is the so-called vertical septum, which is the highest sheet-like aggregate of trabecular myocardium beneath the atrioventricular valve (Webb et al. 1971; Jensen et al. 2014). Early anatomical works suggested it is homologous with the full ventricular septum of mammals and birds (Greil 1903; Robertson 1913). In monitor lizards, the vertical septum is particularly high and $T b \times 3$ and $T b \times 5$ are more expressed in its vicinity (Hanemaaijer et al. 2019). This setting resembles the crest of the ventricular septum of mammals (Moskowitz et al. 2004; Bakker et al. 2008). In mammals and chicken, Tbx5 is expressed in a left-right gradient over the ventricular septum and, in mouse, the absence of $T b \times 5$ results in septal defects (Bruneau et al. 1999, 2001; Koshiba-Takeuchi et al. 2009; Katano et al. 2019). A gradient of $T b \times 5$ was described near the vertical septum of the turtle Trachemys (Koshiba-Takeuchi et al. 2009). However, the turtle Pelodiscus has the gradient over the muscular ridge where it also is in squamates (Fig. 4A; Poelmann et al. 2014). Nonetheless, the original model (Koshiba-Takeuchi et al. 2009) appears valid for animals with a full ventricular septum because $T b x 5 \mathrm{ex}$ pression in the American alligator is confined to the left ventricle with a gradient over the ventricular septum (Fig. 4B; Jensen et al. 2018). The gradient of $T b \times 5$ on the muscular ridge results from its development at the boundary between the embryonic ventricle (that expresses $T b \times 5$ ) and the myocardial outflow tract (Fig. 4A). Opposite to the muscular ridge is the third septum, the bulbuslamelle (Brücke 1852; Greil 1903; Jensen et al. 2014). Like the muscular ridge, it also develops at the boundary of the ventricle and the outflow tract and it too has a gradient of $T b \times 5$ (Fig. 4A).

The full ventricular septum of crocodilians propagates the activating current toward the apical region in a manner that closely resembles the propagation in the ventricular septum of birds and mammals (Fig. 5; Christian and Grigg 1999; Sedmera 2011; Jensen et al. 2018). The ventricular septum receives a dorsal extension of atrioventricular canal-like myocardium (Greil 1903; Swett 1923), which expresses $T b x 3$ and the cutting of which leads to atrioventricular blockade (Fig. 4C,D; Jensen et al. 2018). In monitor lizards, the apical region near the vertical septum activates early (Hanemaaijer et al. 2019); in other reptiles, such as the green anole, leopard gecko, corn snake, the central bearded dragon, and turtles, the electrical propagation occurs in a primitive pattern from base to apex and atrioventricular conduction is not confined to the dorsal part like in crocodilians, mammals, and birds (Fig. 5; Mines 1913; Jensen et al. 2012; Gregorovicova et al. 2018). HNK-1, a marker of the atrioventricular conduction axis in human, chicken, and quail, also identifies the atrioventricular conduction axis in crocodilians (Wessels et al. 1992; Anderson et al. 2018; Kvasilova et al. 2019). Crocodilians appear to lack the equivalent of mammalian bundle branches and Purkinje system and the ventricular activation is long like it is in other reptiles (Fig. 5; Zhao-Xian et al. 1991; Heaton-Jones and King 1994; Jensen et al. 2018; Boukens et al. 2019).

Septation of the outflow tract has received comparatively less attention than the atrial and ventricular septation (Shaner 1962; Hart 1968, 1969; Poelmann et al. 2017). Like in mammals and birds, the wall of the early outflow tract is composed of myocardium up to the pericardial reflection and its inside is almost filled with cardiac jelly (Jensen et al. 2013a; Poelmann et al. 2017). There is only a single narrow lumen. This lumen becomes divided by two opposing mesenchymal ridges that merge. The divided lumen 

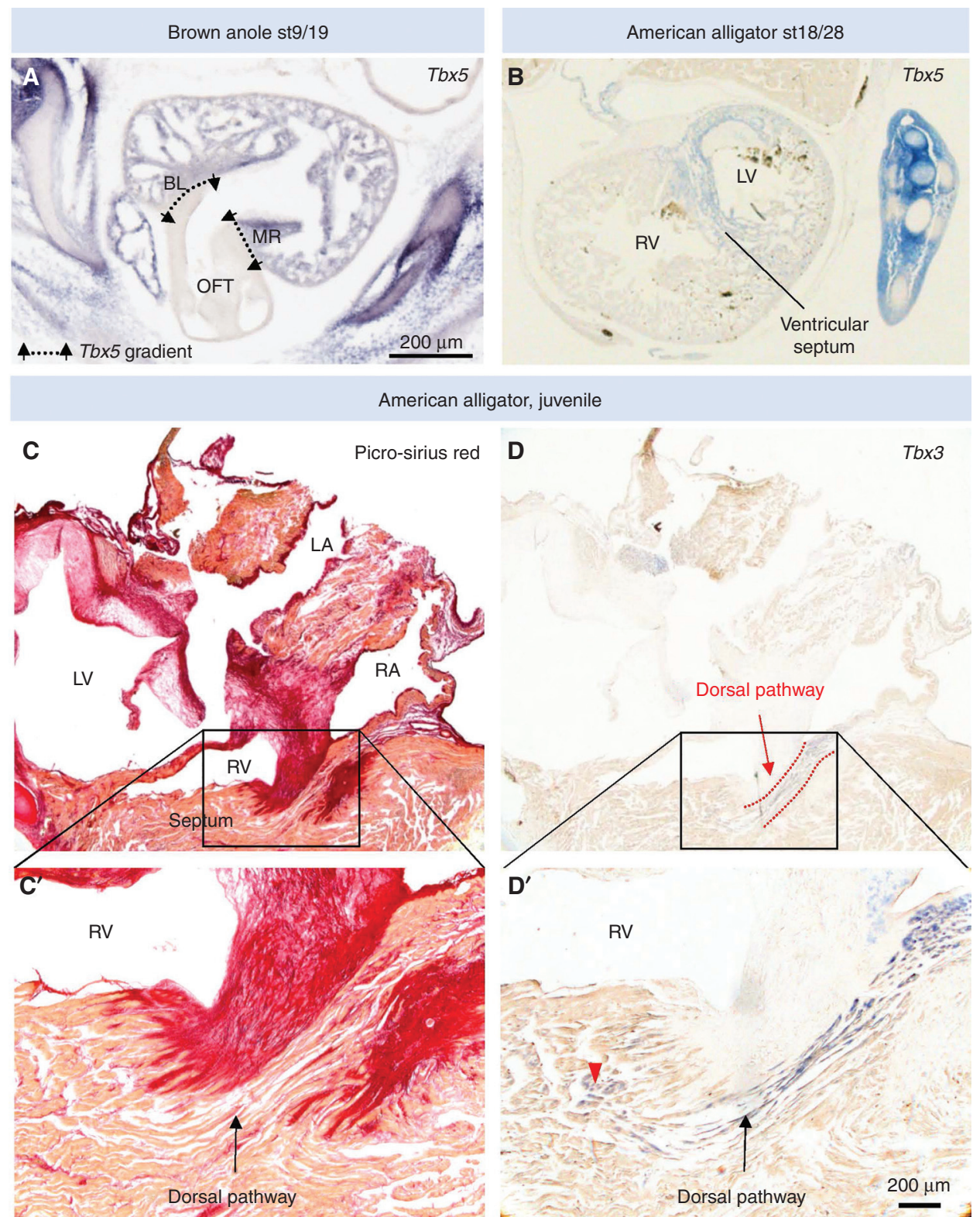

gator, juvenile
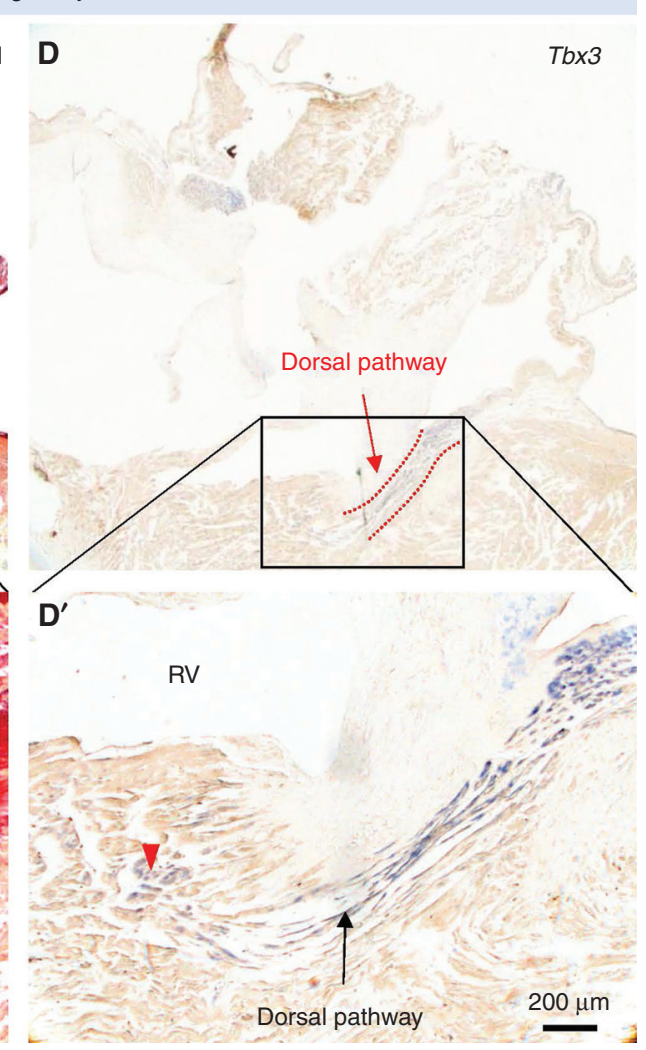

Figure 4. Septum development. (A) In the developing lizard brown anole (Sanger stage 9), $T b \times 5$ is expressed in the ventricle but not in the outflow tract (OFT). As the OFT is being incorporated into the ventricle, two septa can be identified by a gradient of Tbx5, namely, the muscular ridge (MR) and the bulbuslamelle (BL). (Panel adapted from Hanemaaijer et al. 2019 with permission from Company of Biologists (C) 2019.) (B) In the developing American alligator (Ferguson stage 18), Tbx5 is expressed in the left ventricle and much less so in the right ventricle, similar to chicken and mouse (Koshiba-Takeuchi et al. 2009). (C,D) In American alligators, the atria are in contact with the ventricular septum by a dorsal myocardial pathway that expresses $T b x 3$, much like the atrioventricular bundle of the cardiac conduction system of mammals and birds (Hoogaars et al. 2004). (LV) left ventricle, (RV) right ventricle, (LA) left atrium, (RA) right atrium. (The images in $B-D^{\prime}$ are reprinted from Jensen et al. 2018 under the terms of the Creative Commons Attribution License for open-access articles.) 
B. Jensen and V.M. Christoffels
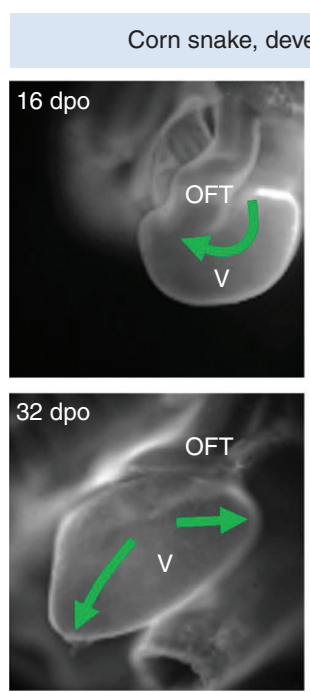
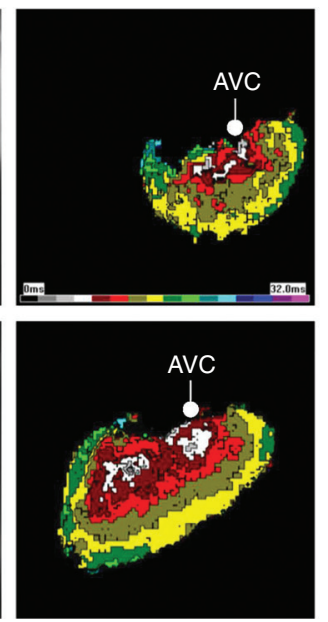
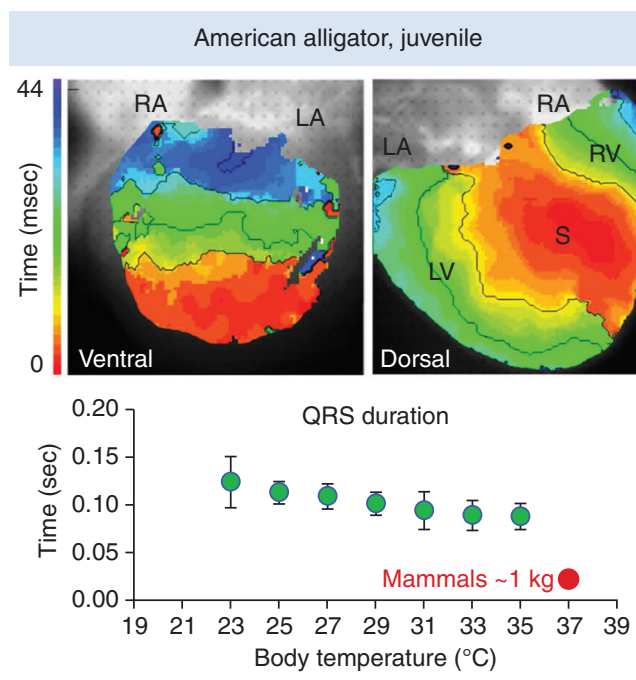

Figure 5. Optical mapping of the electrical activation of the ventricle of reptiles. In the developing corn snake, the ventricular activation initiates in the ventricular base, near the atrioventricular canal (AVC), similar to the activation pattern in other developing and adult squamate reptiles. In the early stages (here exemplified by 16 dpo), the ventricle is broad and the activation front sweeps rightward. In later stages (here exemplified by $32 \mathrm{dpo}$ ), the ventricle is elongated and the activation front again propagates from the vicinity of the AVC to the most distal parts, which are now the apex and the "shoulder" on the left side. The pattern of ventricular activation is then greatly influenced by the shape of the chamber. (Images in the left panel are adapted from Gregorovicova et al. 2018, with permission, from Company of Biologists @ 2018.) In the juvenile American alligator, the ventricular activation initiates in the ventricular septum (S), which on the ventral surface, results in an apex-first activation pattern. This pattern in mammals and birds has been interpreted as resulting from a specialized conduction system. Despite the specialized manner of electrical activation, total ventricular activation as measured by the QRS duration (bottom graph) is slow in alligators, even at mammal-like body temperatures. (LA) left atrium, (LV) left ventricle, (OFT) outflow tract, (RA) right atrium, (RV) right ventricle, (V) single ventricle. (The images in the right panel are reprinted from Jensen et al. 2018 under the terms of the Creative Commons Attribution License for open-access articles.)

consists of a pulmonary channel and an aortic channel. Within the aortic channel and immediately distal to the leading edge of the primary division, an additional mesenchymal ridge divides the aortic channel into a left and a right channel (Greil 1903; Hart 1969; Jensen et al. 2013a). By these divisions, the principle layout of the pulmonary artery and the left and right aorta is established. In some snakes, the left lung is less developed than the right lung, and the left branch of the pulmonary artery develops accordingly (van Soldt et al. 2015). A contribution of neural crest cells to outflow tract septation seems likely given the presence of chondrocytes at the arterial roots (Young 1994; López et al. 2003) and the expression of the transcription factor TFAP $2 \alpha$ in the pharyngeal arches and distal outflow tract (Poelmann et al. 2017). Later in development, mesenchymal-to-myocardial transformation occurs of the proximal part of the division of the pulmonary and aortic channels (Poelmann et al. 2017). This process also occurs in mammals and birds and gives rise to the so-called conal septum (van den Hoff et al. 2001; Yelbuz et al. 2003; Poelmann et al. 2017). The conal septum and the moderator band of the right ventricle resembles the muscular ridge of the reptile ventricle and they are thought to be homologous structures on the basis of anatomy and position (Gasch 1888; Van Mierop and Kutsche 1984, 1985a; Jensen et al. 2013a).

The rare human lesion of a triple outlet right ventricle resembles the reptile setting of two aortas and one pulmonary artery on the right side of 


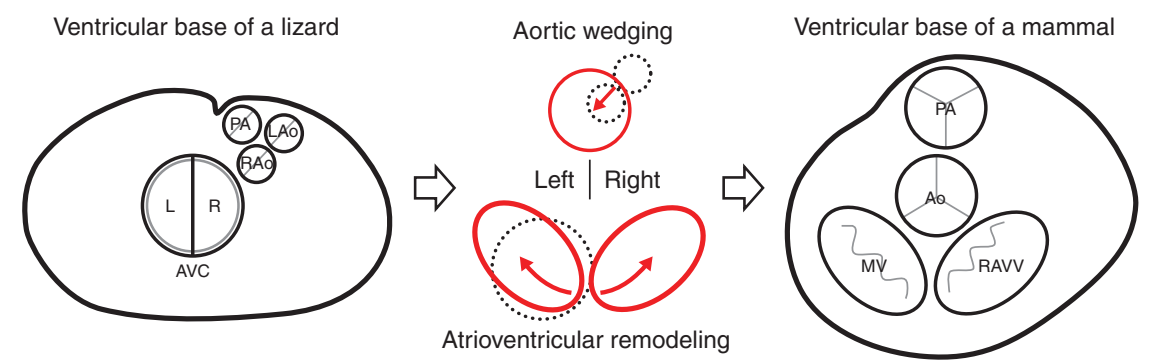

Figure 6. Remodeling (red drawings) of the ventricular base in association with full ventricular septation. The base of the single ventricle of the lizard is characterized by three arterial roots (LAo, RAo, PA) on the ventricular right. To the left of the arterial roots is the single atrioventricular canal (AVC), which is split by the atrial septum into two orifices, each guarded by a single large and medial valve (L, R). To transition in development from an embryonic lizard-like setting to the setting of mammals, the aortic channel must wedge leftward over the ventricular septum and the AVC must expand substantially, particularly on the right. (Ao) aorta, (L) left atrioventricular valve, (LAo) left aorta, (PA) pulmonary artery, (MV) mitral valve, (R) right atrioventricular valve, (RAo) right aorta, (RAVV) right atrioventricular valve. (Image based, in part, on Plate 26 of Heine 1976.)

the ventricle (Cook et al. 2017; Katewa et al. 2019). In contrast, in normal human development, the aortic root will "wedge" leftward between the pulmonary artery and the atrioventricular junction and over the ventricular septum, giving the left ventricle a dedicated outlet (Fig. 6; Asami 1969; Wessels et al. 1992; Anderson et al. 2019). Concomitantly, an atrioventricular remodeling and expansion ensures a persistent communication between the right atrium and the right ventricle (Lamers et al. 1995). It also results in large caliber atrioventricular junctions that, possibly, can better accommodate the greater blood flows associated with endothermy (Fig. 6; Jensen et al. 2013a,b). The aortic wedging and atrioventricular remodeling only occur in all animals that develop a full ventricular septum, namely, mammals, birds, and crocodilians (Hanemaaijer et al. 2019).

\section{CONCLUDING REMARKS}

The intimate phylogenetic relation between reptiles, mammals, and birds has long been recognized by comparative anatomists and physiologists and our understanding of it is now being deepened by comparisons of genomes and expression of homologous genes and proteins. The study of reptile heart development provides an important insight into evolutionary conservation, which, if present, suggests that the pro- cess, or gene, or function in question is important. Unparalleled variation in ventricular septation means the reptiles are attractive models to study the evolutionary and developmental conditions leading to the full ventricular septum. The many similarities of the ventricular septum of crocodilians and mammals illustrate this. But the crocodilian ventricular septum also exemplifies a general challenge we face, namely, what is homology (Shubin et al. 2009)? Even if ventricular septation is by similar processes, the common ancestor of mammals and crocodilians did not have a full ventricular septum and the full septum evolved during the specific histories of mammals and crocodilians. Consequently, the ventricular septum of crocodilians shows both evolutionary conservation and divergence with regard to the ventricular septum of mammal. Ultimately, it is a fairly subjective assessment whether there is evolutionary conservation.

\section{REFERENCES}

Agassiz L. 1857. Embryology of the turtle. Part III. In Contributions to the natural history of the United States of America, Vol 2, pp. 451-643. Little, Brown and Company, Boston.

Alföldi J, Di Palma F, Grabherr M, Williams C, Kong L, Mauceli E, Russell P, Lowe CB, Glor RE, Jaffe JD, et al. 2011. The genome of the green anole lizard and a comparative analysis with birds and mammals. Nature 477 587-591. doi:10.1038/nature10390 
Anderson RH, Jensen B, Mohun TJ, Petersen SE, Aung N, Zemrak F, Planken RN, MacIver DH. 2017. Key questions relating to left ventricular noncompaction cardiomyopathy: is the emperor still wearing any clothes? Can J Cardiol 33: 747-757.

Anderson RH, Mori S, Spicer DE, Sanchez-Quintana D, Jensen B. 2018. The anatomy, development, and evolution of the atrioventricular conduction axis. J Cardiovasc Dev Dis 5: E44. doi:10.3390/jcdd5030044

Anderson RH, Spicer DE, Mohun TJ, Hikspoors JPJM, Lamers WH. 2019. Remodeling of the embryonic interventricular communication in regard to the description and classification of ventricular septal defects. Anat Rec (Hoboken) 302: 19-31. doi:10.1002/ar.24020

Ang KL, Shenje LT, Reuter S, Soonpaa MH, Rubart M, Field LJ, Galiñanes M. 2010. Limitations of conventional approaches to identify myocyte nuclei in histologic sections of the heart. Am J Physiol Cell Physiol 298: C1603-C1609. doi:10.1152/ajpcell.00435.2009

Angelini A, Melacini P, Barbero F, Thiene G. 1999. Evolutionary persistence of spongy myocardium in humans. Circulation 99: 2475. doi:10.1161/01.CIR.99.18.2475

Asami I. 1969. Beitrag zur Entwicklung des Kammerseptums im menschlichen Herzen mit besonderer Berücksichtigung der sogenannten Bulbusdrehung [Contributions to the development of the chamber septa in human hearts, with emphasis on the so-called turning of the bulbus]. Z Anat Entwicklungsgesch 128: 1-17.

Badenhorst D, Hillier LW, Literman R, Montiel EE, Radhakrishnan S, Shen Y, Minx P, Janes DE, Warren WC, Edwards SV, et al. 2015. Physical mapping and refinement of the painted turtle genome (Chrysemys picta) inform amniote genome evolution and challenge turtle-bird chromosomal conservation. Genome Biol Evol 7: 2038-2050. doi:10.1093/gbe/evv119

Bakker ML, Boukens BJ, Mommersteeg MT, Brons JF, Wakker V, Moorman AF, Christoffels VM. 2008. Transcription factor Tbx 3 is required for the specification of the atrioventricular conduction system. Circ Res 102: 13401349. doi:10.1161/CIRCRESAHA.107.169565

Bakkers J. 2011. Zebrafish as a model to study cardiac development and human cardiac disease. Cardiovasc Res 91: 279-288. doi:10.1093/cvr/cvr098

Bellmann K, Perrot A, Rickert-Sperling S. 2016. Human genetics of ventricular septal defect. In Congenital heart diseases: the broken heart: clinical features, human genetics and molecular pathways (ed. Rickert-Sperling S, Kelly RG, Driscoll DJ), pp. 307-328. Springer, Vienna.

Benninghoff A. 1933. Das Herz [The heart]. In Handbuch der vergleichende anatomie der wirbeltiere (ed. Bolk $\mathrm{L}$, Göppert E, Kallius E, Lubosch W), pp. 467-555. Urban \& Schwarzenberg, Berlin.

Bers DM. 2002. Cardiac excitation-contraction coupling. Nature 415: 198-205. doi:10.1038/415198a

Bertens LMF, Richardson MK, Verbeek FJ. 2010. Analysis of cardiac development in the turtle Emys orbicularis (testudines: wmidydae) using 3-D computer modeling from histological sections. Anat $\operatorname{Rec} 293$ : 1101-1114. doi:10 $.1002 /$ ar.21162

Boback SM, Dichter EK, Mistry HL. 2012. A developmental staging series for the African house snake, Boaedon
(Lamprophis) fuliginosus. Zoology 115: 38-46. doi:10 .1016/j.zool.2011.09.001

Boughner JC, Buchtová M, Fu K, Diewert V, Hallgrímsson B, Richman JM. 2007. Embryonic development of Python sebae-I: staging criteria and macroscopic skeletal morphogenesis of the head and limbs. Zoology 110: 212-230. doi:10.1016/j.zool.2007.01.005

Boukens BJ, Christoffels VM. 2012. Electrophysiological patterning of the heart. Pediatr Cardiol 33: 900-906. doi:10 .1007/s00246-012-0237-4

Boukens BJ, Kristensen DL, Filogonio R, Carreira LBT, Sartori MR, Abe AS, Currie S, Joyce W, Conner J, Opthof T, et al. 2019. The electrocardiogram of vertebrates: evolutionary changes from ectothermy to endothermy. Prog Biophys Mol Biol 144: 16-29. doi:10.1016/j.pbiomolbio .2018 .08 .005

Brockman HL, Kennedy JP. 1962. Interventricular septal defect in Alligator mississippiensis Daudin. Tex Rep Biol Med 20: 719-720.

Brücke E. 1852. Beiträge zur vergleichenden anatomie und physiologie des gefäss-systemes [Contributions to comparative anatomy and physiology of the vascular systems] Denkschriften der kaiserliche Akademie der Wissenschaften - Mathematisch-Naturwissenschaftliche Classe 3: 335367.

Bruneau BG. 2008. The developmental genetics of congenital heart disease. Nature 451: 943-948. doi:10.1038/na ture06801

Bruneau BG, Logan M, Davis N, Levi T, Tabin CJ, Seidman JG, Seidman CE. 1999. Chamber-specific cardiac expression of Tbx5 and heart defects in Holt-Oram syndrome. Dev Biol 211: 100-108. doi:10.1006/dbio.1999.9298

Bruneau BG, Nemer G, Schmitt JP, Charron F, Robitaille L, Caron S, Conner DA, Gessler M, Nemer M, Seidman CE, et al. 2001. A murine model of Holt-Oram syndrome defines roles of the T-box transcription factor Tbx 5 in cardiogenesis and disease. Cell 106: 709-721. doi:10 .1016/S0092-8674(01)00493-7

Burggren WW, Johansen K. 1982. Ventricular hemodynamics in the monitor lizard Varanus exanthematicus: pulmonary and systemic pressure separation. J Exp Biol 96: 343-354.

Burggren W, Farrell AP, Lillywhite HB. 1998. Vertebrate cardiovascular systems. In Handbook of physiology (ed. Dantzler, WH), pp. 215-308. Oxford University Press, Oxford.

Burkhard S, van Eif V, Garric L, Christoffels VM, Bakkers J. 2017. On the evolution of the cardiac pacemaker. J Cardiovasc Dev Dis 4: E4.

Castoe T, de Koning AJ, Hall K, Yokoyama K, Gu W, Smith E, Feschotte C, Uetz P, Ray D, Dobry J, et al. 2011. Sequencing the genome of the Burmese python (Python molurus bivittatus) as a model for studying extreme adaptations in snakes. Genome Biol 12: 406. doi:10.1186/gb2011-12-7-406

Christian E, Grigg GC. 1999. Electrical activation of the ventricular myocardium of the crocodile Crocodylus johnstoni: a combined microscopic and electrophysiological study. Comp Biochem Physiol A Comp Physiol 123: 17-23. doi:10.1016/S1095-6433(99)00024-0 
Cook AC, Tran VH, Spicer DE, Rob JMH, Sridharan S, Taylor A, Anderson RH, Jensen B. 2017. Sequential segmental analysis of the crocodilian heart. J Anat 231: 484-499.

Crossley DA, Burggren WW. 2009. Development of cardiac form and function in ectothermic sauropsids. J Morphol 270: 1400-1412. doi:10.1002/jmor.10764

Crossley DA, Burggren WW, Reiber CL, Altimiras J, Rodnick KJ. 2016. Mass transport: circulatory system with emphasis on nonendothermic species. Compr Physiol 7: 17-66. doi:10.1002/cphy.c150010

D’Amato G, Luxán G, Del Monte-Nieto G, Martínez-Poveda B, Torroja C, Walter W, Bochter MS, Benedito R, Cole S, Martinez F, et al. 2016. Sequential notch activation regulates ventricular chamber development. Nat Cell Biol 18: 7-20. doi:10.1038/ncb3280

de Bakker BS, de Jong KH, Hagoort J, de Bree K, Besselink CT, de Kanter FE, Veldhuis T, Bais B, Schildmeijer R, Ruijter JM, et al. 2016. An interactive three-dimensional digital atlas and quantitative database of human development. Science 354: aag0053 doi:10.1126/science .aag0053

de la Cruz MV, Sanchez Gomez C, Arteaga MM, Arguello C. 1977. Experimental study of the development of the truncus and the conus in the chick embryo. J Anat 123: 661686.

Del Monte-Nieto G, Ramialison M, Adam AAS, Wu B, Aharonov A, D'Uva G, Bourke LM, Pitulescu ME, Chen H, de la Pompa JL, et al. 2018. Control of cardiac jelly dynamics by NOTCH1 and NRG1 defines the building plan for trabeculation. Nature 557: 439-445. doi:10.1038/ s41586-018-0110-6

Delorme B, Dahl E, Jarry-Guichard T, Marics I, Briand JP, Willecke K, Gros D, Théveniau-Ruissy M. 1995. Developmental regulation of connexin 40 gene expression in mouse heart correlates with the differentiation of the conduction system. Dev Dyn 204: 358-371. doi:10.1002/aja 1002040403

Diogo R, Kelly RG, Christiaen L, Levine M, Ziermann JM, Molnar JL, Noden DM, Tzahor E. 2015. A new heart for a new head in vertebrate cardiopharyngeal evolution. $\mathrm{Na}$ ture 520: 466-473. doi:10.1038/nature 14435

Du WG, Ye H, Zhao B, Warner DA, Shine R. 2010. Thermal acclimation of heart rates in reptilian embryos. PLOS ONE 5: e15308. doi:10.1371/journal.pone.0015308

Du WG, Ye H, Zhao B, Pizzatto L, Ji X, Shine R. 2011. Patterns of interspecific variation in the heart rates of embryonic reptiles. PLoS ONE 6: e29027. doi:10.1371/ journal.pone.0029027

Duan J, Sanggaard KW, Schauser L, Lauridsen SE, Enghild JJ, Schierup MH, Wang T. 2017. Transcriptome analysis of the response of Burmese python to digestion. Gigascience 6: 1-18. doi:10.1093/gigascience/gix057

Else PL, Hulbert AJ. 1987. Evolution of mammalian endothermic metabolism: "leaky" membranes as a source of heat. Am J Physiol 22: R1-R7.

Faber JW, Boukens BJ, Oostra RJ, Moorman AFM, Christoffels VM, Jensen B. 2019. Sinus venosus incorporation: contentious issues and operational criteria for developmental and evolutionary studies. J Anat 234: 583-591. doi:10.1111/joa.12962

Farrell AP, Gamperl AK, Francis ETB. 1998. Comparative aspects of heart morphology. In Morphology G: the visceral organs (ed. Gans C, Gaunt AS), pp. 375424. Society for the Study of Amphibians and Reptiles, Ithaca, NY.

Ferguson MWJ. 1985. Reproductive biology and embryology of the crocodilians. In Development A (ed. Gans C, Billett F, Maderson PFA), pp. 331-491. Wiley, New York.

Finsterer J, Stollberger C, Towbin JA. 2017. Left ventricular noncompaction cardiomyopathy: cardiac, neuromuscular, and genetic factors. Nat Rev Cardiol 14: 224-237.

Freedom RM, Yoo SJ, Perrin D, Taylor G, Petersen S, Anderson RH. 2005. The morphological spectrum of ventricular noncompaction. Cardiol Young 15: 345-364.

Gasch FR. 1888. Beiträge zur vergleichenden anatomie des herzens der vögel und reptilien [Contributions to comparative anatomy of the hearts of birds and reptiles]. Archiv für Naturgeschichte 54: 119-152.

Gegenbaur C. 1878. Elements of comparative anatomy. MacMillan, London.

Geiser F, Stawski C, Wacker CB, Nowack J. 2017. Phoenix from the ashes: fire, torpor, and the evolution of mammalian endothermy. Front Physiol 8: 842. doi:10.3389/ fphys.2017.00842

Georges A, Li Q, Lian J, O'Meally D, Deakin J, Wang Z, Zhang P, Fujita M, Patel HR, Holleley CE, et al. 2015. High-coverage sequencing and annotated assembly of the genome of the Australian dragon lizard Pogona vitticeps. Gigascience 4: 45. doi:10.1186/s13742-015-0085-2

Goodrich ES. 1930. Studies on the structure and development of vertebrates, pp. 536-577. Macmillan, London.

Goor DA, Dische R, Lillehei CW. 1972. The conotruncus. I: its normal inversion and conus absorption. Circulation 46: 375-384. doi:10.1161/01.CIR.46.2.375

Grant RT, Regnier M. 1926. The comparative anatomy of the cardiac coronary vessels. Heart 13: 285-317.

Green RE, Braun EL, Armstrong J, Earl D, Nguyen N, Hickey G, Vandewege MW, St John JA, Capella-Gutierrez S, Castoe TA, et al. 2014. Three crocodilian genomes reveal ancestral patterns of evolution among archosaurs. Science 346: 1254449. doi:10.1126/science. 1254449

Greenbaum E, Carr JL. 2002. Staging criteria for embryos of the spiny softshell turtle, Apalone spinifera (testudines: Trionychidae). J Morphol 254: 272-291. doi:10.1002/ jmor.10036

Gregorovicova M, Zahradnicek O, Tucker AS, Velensky P, Horacek I. 2012. Embryonic development of the monitor lizard, Varanus indicus. Amphib Reptil 33: 451-468. doi:10.1163/15685381-00002849

Gregorovicova M, Sedmera D, Jensen B. 2018. Relative position of the atrioventricular canal determines the electrical activation of developing reptile ventricles. J Exp Biol 221(Pt 11): jeb178400. doi:10.1242/jeb.178400

Greil A. 1903. Beiträge zur vergleichenden Anatomie und entwicklungsgeschichte des Herzens und des Truncus arteriosus der Wirbelthiere [Contributions to comparative anatomy and development of the hearts and truncus arteriosus of vertebrates]. Morph Jahrbuch 31: 123-310.

Grimes AC, Kirby ML. 2009. The outflow tract of the heart in fishes: anatomy, genes and evolution. J Fish Biol 74: $983-$ 1036. doi:10.1111/j.1095-8649.2008.02125.x

Habets PE, Moorman AF, Clout DE, van Roon MA, Lingbeek M, van Lohuizen M, Campione M, Christoffels VM. 
2002. Cooperative action of Tbx2 and Nkx2.5 inhibits ANF expression in the atrioventricular canal: implications for cardiac chamber formation. Genes Dev 16: 12341246. doi:10.1101/gad.222902

Hagensen MK, Abe AS, Falk E, Wang T. 2008. Physiological importance of the coronary arterial blood supply to the rattlesnake heart. J Exp Biol 211: 3588-3593. doi:10.1242/ jeb.024489

Hamburger V, Hamilton HL. 1992. A series of normal stages in the development of the chick embryo. 1951. Dev Dyn 195: 231-272. doi:10.1002/aja.1001950404

Hanemaaijer J, Gregorovicova M, Nielsen JM, Moorman AFM, Wang T, Planken RN, Christoffels VM, Sedmera D, Jensen B. 2019. Identification of the building blocks of ventricular septation in monitor lizards (Varanidae). Development 146: dev177121. doi:10.1242/dev.177121

Hart NH. 1968. Formation of septa in the bulbus cordis of a turtle and a lizard. J Morphol 125: 1-21. doi:10.1002/jmor .1051250102

Hart NH. 1969. The bulbus cordis and its septa in Sphenodon punctatus. J Morphol 129: 369-374. doi:10.1002/ jmor.1051290308

Harvey W. 1995. The anatomical exercises: de motu cordis and de circulatione sanguinis (English translation). Dover, New York

Heaton-Jones TG, King RR. 1994. Characterization of the electrocardiogram of the American alligator (Alligator mississippiensis). J Zoo Wildl Med 25: 40-47.

Heine H. 1976. Stammes-un entwicklungsgeschichte des herzens lungenatmender wirbeltiere [Evolution and development of the heart of lunged vertebrates]. Abhandlungen der Senckenbergischen Naturforschenden Gesellschaft 535: 1-152.

Hicks JW, Wang T. 2012. The functional significance of the reptilian heart: new insights into an old question. In Ontogeny and phylogeny of the vertebrate heart (ed. Sedmera D, Wang T), pp. 207-227. Springer, New York.

Hillman SS, Hedrick MS. 2015. A meta-analysis of in vivo vertebrate cardiac performance: implications for cardiovascular support in the evolution of endothermy. J Exp Biol 218: 1143-1150. doi:10.1242/jeb.118372

Hirakow R. 1970. Ultrastructural characteristics of the mammalian and sauropsidan heart. Am J Cardiol 25: 195-203. doi:10.1016/0002-9149(70)90579-5

Hirose K, Payumo AY, Cutie S, Hoang A, Zhang H, Guyot R, Lunn D, Bigley RB, Yu H, Wang J, et al. 2019. Evidence for hormonal control of heart regenerative capacity during endothermy acquisition. Science 364: 184-188.

Hoffman JI, Kaplan S. 2002. The incidence of congenital heart disease. J Am Coll Cardiol 39: 1890-1900. doi:10 .1016/S0735-1097(02)01886-7

Hoffmann S, Berger IM, Glaser A, Bacon C, Li L, Gretz N, Steinbeisser H, Rottbauer W, Just S, Rappold G. 2013. Islet1 is a direct transcriptional target of the homeodomain transcription factor Shox2 and rescues the Shox2mediated bradycardia. Basic Res Cardiol 108: 339. doi:10 $.1007 / \mathrm{s} 00395-013-0339-\mathrm{z}$

Holmes EB. 1975. A reconsideration of the phylogeny of the tetrapod heart. J Morphol 147: 209-228. doi:10.1002/ jmor.1051470207
Hoogaars WMH, Tessari A, Moorman AFM, de Boer PAJ, Hagoort J, Soufan AT, Campione M, Christoffels VM. 2004. The transcriptional repressor Tbx3 delineates the developing central conduction system of the heart. Cardiovasc Res 62: 489-499. doi:10.1016/j.cardiores.2004.01 .030

Ishimatsu A, Hicks JW, Heisler N. 1988. Analysis of intracardiac shunting in the lizard, Varanus niloticus: a new model based on blood oxygen levels and microsphere distribution. Respir Physiol 71: 83-100. doi:10.1016/ 0034-5687(88)90117-X

Jacyniak K, Vickaryous MK. 2018. Constitutive cardiomyocyte proliferation in the leopard gecko (Eublepharis macularius). J Morphol 279: 1355-1367. doi:10.1002/jmor .20850

Jensen B, Wang T. 2009. Hemodynamic consequences of cardiac malformations in two juvenile ball pythons ( $P y$ thon regius). J Zoo Wildl Med 40: 752-756. doi:10.1638/ 2008-0209.1

Jensen B, Nielsen JM, Axelsson M, Pedersen M, Löfman C, Wang T. 2010. How the python heart separates pulmonary and systemic blood pressures and blood flows. J Exp Biol 213: 1611-1617. doi:10.1242/jeb.030999

Jensen B, Boukens BJ, Postma AV, Gunst QD, van den Hoff MJ, Moorman AF, Wang T, Christoffels VM. 2012. Identifying the evolutionary building blocks of the cardiac conduction system. PLoS ONE 7: e44231. doi:10.1371/ journal.pone.0044231

Jensen B, van den Berg G, van den Doel R, Oostra RJ, Wang T, Moorman AF. 2013a. Development of the hearts of lizards and snakes and perspectives to cardiac evolution. PLoS ONE 8: e63651. doi:10.1371/journal.pone.0063651

Jensen B, Wang T, Christoffels VM, Moorman AF. 2013b. Evolution and development of the building plan of the vertebrate heart. Biochim Biophys Acta 1833: 783-794. doi:10.1016/j.bbamcr.2012.10.004

Jensen B, Moorman AF, Wang T. 2014. Structure and function of the hearts of lizards and snakes. Biol Rev Camb Philos Soc 89: 302-336. doi:10.1111/brv.12056

Jensen B, Agger P, de Boer BA, Oostra RJ, Pedersen M, van der Wal AC, Nils Planken R, Moorman AF. 2016a. The hypertrabeculated (noncompacted) left ventricle is different from the ventricle of embryos and ectothermic vertebrates. Biochim Biophys Acta 1863: 1696-1706. doi:10 $.1016 /$ j.bbamcr.2015.10.018

Jensen B, Elfwing M, Elsey RM, Wang T, Crossley DA II. 2016b. Coronary blood flow in the anesthetized American alligator (Alligator mississippiensis). Comp Biochem Physiol A Mol Integr Physiol 191: 44-52. doi:10.1016/j.cbpa .2015 .09 .018

Jensen B, van der Wal AC, Moorman AFM, Christoffels VM. 2017a. Excessive trabeculations in noncompaction do not have the embryonic identity. Int J Cardiol 227: 325-330. doi:10.1016/j.ijcard.2016.11.089

Jensen B, Vesterskov S, Boukens BJ, Nielsen JM, Moorman AFM, Christoffels VM, Wang T. 2017b. Morpho-functional characterization of the systemic venous pole of the reptile heart. Sci Rep 7: 6644. doi:10.1038/s41598017-06291-z

Jensen B, Boukens BJ, Crossley DA, Conner J, Mohan RA, van Duijvenboden K, Postma AV, Gloschat CR, Elsey RM, 
Sedmera D, et al. 2018. Specialized impulse conduction pathway in the alligator heart. eLife 7: e32120.

Jensen B, Wang T, Moorman AFM. 2019. Evolution and development of the atrial septum. Anat Rec 302: 32-48. doi:10.1002/ar.23914

Joyce W, Axelsson M, Altimiras J, Wang T. 2016. In situ cardiac perfusion reveals interspecific variation of intraventricular flow separation in reptiles. J Exp Biol 219: 2220-2227. doi:10.1242/jeb.139543

Joyce W, Crossley DA, Wang T, Jensen B. 2019. Smooth muscle in cardiac chambers is common in turtles and extensive in the emydid turtle, Trachemys scripta. Anat $\operatorname{Rec}$ doi:10.1002/ar.24257

Kardong KV. 2006. Vertebrates: comparative anatomy, function, evolution. McGraw-Hill, Boston.

Katano W, Moriyama Y, Takeuchi JK, Koshiba-Takeuchi K. 2019. Cardiac septation in heart development and evolution. Dev Growth Differ 61: 114-123.

Katewa A, Sahu B, Jain V, Anderson RH. 2019. Triple outlet right ventricle, with duplication of the aortic root and intrapericardial ascending aorta. World J Pediatr Congenit Heart Surg doi:10.1177/2150135117735470

Keith A, Flack M. 1907. The form and nature of the muscular connections between the primary divisions of the vertebrate heart. J Anat Physiol 41: 172-189.

Kelly RG, Buckingham ME, Moorman AF. 2014. Heart fields and cardiac morphogenesis. Cold Spring Harb Perspect Med 4: a015750. doi:10.1101/cshperspect.a015750

Khannoon ER, Zahradnicek O. 2017. Postovipositional development of the sand snake Psammophis sibilans (serpentes: lamprophiidae) in comparison with other snake species. Acta Zool 98: 144-153. doi:10.1111/azo.12157

Kohmoto T, Argenziano M, Yamamoto N, Vliet KA, Gu A, DeRosa CM, Fisher PE, Spotnitz HM, Burkhoff D, Smith CR. 1997. Assessment of transmyocardial perfusion in alligator hearts. Circulation 95: 1585-1591. doi:10.1161/ 01.CIR.95.6.1585

Koibuchi N, Chin MT. 2007. CHF1/Hey2 plays a pivotal role in left ventricular maturation through suppression of ectopic atrial gene expression. Circ Res 100: 850-855. doi:10 $.1161 / 01 . R E S .0000261693 .13269 . b f$

Kokubo N, Matsuura M, Onimaru K, Tiecke E, Kuraku S, Kuratani S, Tanaka M. 2010. Mechanisms of heart development in the Japanese lamprey, Lethenteron japonicum. Evol Dev 12: 34-44. doi:10.1111/j.1525-142X .2009.00389.x

Koshiba-Takeuchi K, Mori AD, Kaynak BL, Cebra-Thomas J, Sukonnik T, Georges RO, Latham S, Beck L, Henkelman RM, Black BL, et al. 2009. Reptilian heart development and the molecular basis of cardiac chamber evolution. Nature 461: 95-98. doi:10.1038/nature08324

Kraus F, Haenig B, Kispert A. 2001. Cloning and expression analysis of the mouse T-box gene tbx20. Mech Dev 100: 87-91. doi:10.1016/S0925-4773(00)00499-8

Krogh A. 1929. The progress of physiology. Am J Physiol 90: 243-251. doi:10.1152/ajplegacy.1929.90.2.243

Kroneman JGH, Faber JW, Schouten JCM, Wolschrijn CF, Christoffels VM, Jensen B. 2019. Comparative analysis of avian hearts provides little evidence for variation among species with acquired endothermy. J Morphol 280: 395410.
Kvasilova A, Gregorovicova M, Kundrat M, Sedmera D. 2019. HNK-1 in morphological study of development of the cardiac conduction system in selected groups of sauropsida. Anat Rec (Hoboken) 302: 69-82. doi:10.1002/ar .23925

Kvon EZ, Kamneva OK, Melo US, Barozzi I, Osterwalder M, Mannion BJ, Tissières V, Pickle CS, Plajzer-Frick I, Lee EA, et al. 2016. Progressive loss of function in a limb enhancer during snake evolution. Cell 167: 633-642. e11. doi:10.1016/j.cell.2016.09.028

Lamers WH, Virágh S, Wessels A, Moorman AF, Anderson RH. 1995. Formation of the tricuspid valve in the human heart. Circulation 91: 111-121. doi:10.1161/01.CIR.91.1 .111

Leite CAC, Taylor EW, Wang T, Abe AS, de Andrade DOV. 2013. Ablation of the ability to control the right-to-left cardiac shunt does not affect oxygen uptake, specific dynamic action or growth in the rattlesnake Crotalus durissus. J Exp Biol 216: 1881-1889. doi:10.1242/jeb .083840

Leone M, Magadum A, Engel FB. 2015. Cardiomyocyte proliferation in cardiac development and regeneration: a guide to methodologies and interpretations. Am J Physiol Heart Circ Physiol 309: H1237-H1250. doi:10.1152/aj pheart.00559.2015

Lillywhite HB, Zippel KC, Farrell AP. 1999. Resting and maximal heart rates in ectothermic vertebrates. Comp Biochem Physiol A Mol Integr Physiol 124: 369-382. doi:10.1016/S1095-6433(99)00129-4

Lind AL, Lai YY, Mostovoy Y, Holloway AK, Iannucci A, Mak AC, Fondi M, Orlandini V, Eckalbar WL, Milan M, et al. 2019. Genome of the Komodo dragon reveals adaptations in the cardiovascular and chemosensory systems of monitor lizards. Nat Ecol Evol 3: 1241.

López D, Durán AC, de Andrés AV, Guerrero A, Blasco M, Sans-Coma V. 2003. Formation of cartilage in the heart of the Spanish terrapin, Mauremys leprosa (Reptilia, Chelonia). J Morphol 258: 97-105. doi:10.1002/jmor.10134

MacKinnon MR, Heatwole H. 1981. Comparative cardiac anatomy of the reptilia. IV: the coronary arterial circulation. J Morphol 170: 1-27. doi:10.1002/jmor.1051700102

Manner J, Yelbuz TM. 2019. Functional morphology of the cardiac jelly in the tubular heart of vertebrate embryos. J Cardiovasc Dev Dis 6: E12.

Mines GR. 1913. On dynamic equilibrium in the heart. J Physiol 46: 349-383. doi:10.1113/jphysiol.1913.sp001596

Moorman AF, Christoffels VM. 2003. Cardiac chamber formation: development, genes, and evolution. Physiol Rev 83: 1223-1267. doi:10.1152/physrev.00006.2003

Moskowitz IP, Pizard A, Patel VV, Bruneau BG, Kim JB, Kupershmidt S, Roden D, Berul CI, Seidman CE, Seidman JG. 2004. The T-box transcription factor Tbx5 is required for the patterning and maturation of the murine cardiac conduction system. Development 131: 41074116. doi: $10.1242 / \mathrm{dev} .01265$

Mullen RK. 1967. Comparative electrocardiography of the squamata. Physiol Zool 40: 114-126.

Nathan H, Gloobe H. 1970. Myocardial atrio-venous junctions and extensions (sleeves) over the pulmonary and caval veins: anatomical observations in various mammals. Thorax 25: 317-324. doi:10.1136/thx.25.3.317 
Olson EN. 2006. Gene regulatory networks in the evolution and development of the heart. Science 313: 1922-1927. doi:10.1126/science.1132292

Opthof T. 1988. The mammalian sinoatrial node. Cardiovasc Drugs Ther 1: 573-597. doi:10.1007/BF02125744

Ostadal B, Ostadalova I, Dhalla NS. 1999. Development of cardiac sensitivity to oxygen deficiency: comparative and ontogenetic aspects. Physiol Rev 79: 635-659. doi:10 $.1152 /$ physrev.1999.79.3.635

Park DS, Fishman GI. 2017. Development and function of the cardiac conduction system in health and disease. $J$ Cardiovasc Dev Dis 4: 7.

Perry BW, Card DC, McGlothlin JW, Pasquesi GIM, Adams RH, Schield DR, Hales NR, Corbin AB, Demuth JP, Hoffmann FG, et al. 2018. Molecular adaptations for sensing and securing prey and insight into amniote genome diversity from the garter snake genome. Genome Biol Evol 10: 2110-2129. doi:10.1093/gbe/evy157

Poelmann RE, Gittenberger-de Groot AC. 2019. Development and evolution of the metazoan heart. Dev Dyn 248: 634-656.

Poelmann RE, Groot AC, Vicente-Steijn R, Wisse LJ, Bartelings MM, Everts S, Hoppenbrouwers T, Kruithof BP, Jensen B, de Bruin PW, et al. 2014. Evolution and development of ventricular septation in the amniote heart. PLoS ONE 9: e106569. doi:10.1371/journal.pone.0106569

Poelmann RE, Gittenberger-de Groot AC, Biermans MWM, Dolfing AI, Jagessar A, van Hattum S, Hoogenboom A, Wisse LJ, Vicente-Steijn R, de Bakker MAG, et al. 2017. Outflow tract septation and the aortic arch system in reptiles: lessons for understanding the mammalian heart. Evodevo 8: 9. doi:10.1186/s13227-017-0072-z

Poulsen CB, Wang T, Assersen K, Iversen NK, Damkjaer M. 2018. Does mean arterial blood pressure scale with body mass in mammals? Effects of measurement of blood pressure. Acta Physiol (Oxf) 222: e13010. doi:10.1111/apha .13010

Rana MS, Horsten NCA, Tesink-Taekema S, Lamers WH, Moorman AFM, van den Hoff MJB. 2007. Trabeculated right ventricular free wall in the chicken heart forms by ventricularization of the myocardium initially forming the outflow tract. Circ Res 100: 1000-1007. doi:10.1161/ 01.RES.0000262688.14288.b8

Randall D, Burggren WW, French K, Eckert R. 2002. Eckert animal physiology. W.H. Freeman, New York.

Remme CA, Verkerk AO, Hoogaars WM, Aanhaanen WT, Scicluna BP, Annink C, van den Hoff MJ, Wilde AA, van Veen TA, Veldkamp MW, et al. 2009. The cardiac sodium channel displays differential distribution in the conduction system and transmural heterogeneity in the murine ventricular myocardium. Basic Res Cardiol 104: 511-522. doi:10.1007/s00395-009-0012-8

Rhee S, Chung JI, King DA, D'Amato G, Paik DT, Duan A, Chang A, Nagelberg D, Sharma B, Jeong Y, et al. 2018. Endothelial deletion of Ino80 disrupts coronary angiogenesis and causes congenital heart disease. Nat Commun 9: 368. doi:10.1038/s41467-017-02796-3

Richardson MK. 1999. Vertebrate evolution: the developmental origins of adult variation. Bioessays 21: 604-613. doi:10.1002/(SICI)1521-1878(199907)21:7<604::AID-BI ES9>3.0.CO;2-U
Riquelme CA, Magida JA, Harrison BC, Wall CE, Marr TG, Secor SM, Leinwand LA. 2011. Fatty acids identified in the Burmese python promote beneficial cardiac growth. Science 334: 528-531. doi:10.1126/science. 1210558

Robertson JI. 1913. The development of the heart and vascular system of Lepidosiren paradoxa. Quart J Micr Sci s259: 53-132.

Röse C. 1889. Zur entwicklungsgeschichte des säugethierherzens [Development of the mammal heart]. Morphol Jahrb 15: 436-456.

Röse C. 1890. Beitrage zur vergleichenden anatomie des herzens der wirbelthiere. Morphol Jahrb 16: 27-96.

Rowlatt U. 1990. Comparative anatomy of the heart of mammals. Zool J Linn Soc 98: 73-110. doi:10.1111/j.1096-3642 .1990.tb01220.x

Runciman SI, Gannon BJ, Baudinette RV. 1995. Central cardiovascular shunts in the perinatal marsupial. Anat Rec 243: 71-83. doi:10.1002/ar.1092430109

Sanger TJ, Losos JB, Gibson-Brown JJ. 2008. A developmental staging series for the lizard genus Anolis: a new system for the integration of evolution, development, and ecology. J Morphol 269: 129-137. doi:10.1002/jmor .10563

Sanggaard KW, Danielsen CC, Wogensen L, Vinding MS, Rydtoft LM, Mortensen MB, Karring H, Nielsen NC, Wang T, Thøgersen IB, et al. 2012. Unique structural features facilitate lizard tail autotomy. PLOS ONE 7: e51803. doi:10.1371/journal.pone.0051803

Secor SM, Diamond J. 1998. A vertebrate model of extreme physiological regulation. Nature 395: 659-662. doi:10 $.1038 / 27131$

Sedmera D. 2011. Function and form in the developing cardiovascular system. Cardiovasc Res 91: 252-259. doi:10 $.1093 / \mathrm{cvr} / \mathrm{cvr} 062$

Sedmera D, Ostadal B. 2012. Ontogenesis of myocardial function. In Ontogeny and phylogeny of the vertebrate heart (ed. Sedmera D, Wang T), pp. 147-175. Springer, New York.

Sedmera D, Reckova M, DeAlmeida A, Coppen SR, Kubalak SW, Gourdie RG, Thompson RP. 2003. Spatiotemporal pattern of commitment to slowed proliferation in the embryonic mouse heart indicates progressive differentiation of the cardiac conduction system. Anat Rec A Discov Mol Cell Evol Biol 274A: 773-777. doi:10.1002/ar.a .10085

Seymour RS. 1987. Scaling of cardiovascular physiology in snakes. Am Zool 27: 97-109. doi:10.1093/icb/27.1.97

Seymour RS, Blaylock AJ. 2000. The principle of Laplace and scaling of ventricular wall stress and blood pressure in mammals and birds. Physiol Biochem Zool 73: 389-405. doi: $10.1086 / 317741$

Shaner RF. 1962. Comparative development of the bulbus and ventricles of the vertebrate heart with special reference to Spitzer's theory of heart malformations. Anat Rec 142: 519-529. doi:10.1002/ar.1091420409

Shiels HA, Galli GL. 2014. The sarcoplasmic reticulum and the evolution of the vertebrate heart. Physiology (Bethesda) 29: 456-469.

Shiels HA, White E. 2008. The Frank-Starling mechanism in vertebrate cardiac myocytes. J Exp Biol 211: 2005-2013. doi:10.1242/jeb.003145 
Shubin N, Tabin C, Carroll S. 2009. Deep homology and the origins of evolutionary novelty. Nature 457: 818-823. doi:10.1038/nature07891

Sissman NJ. 1970. Developmental landmarks in cardiac morphogenesis: comparative chronology. Am J Cardiol 25: 141-148. doi:10.1016/0002-9149(70)90575-8

Sklansky MS, Levy DJ, Elias WT, Morris P, Grossfeld PD, Kashani IA, Shaughnessy RD, Rothman A. 2001. Reptilian echocardiography: insights into ontogeny and phylogeny? Echocardiography 18: 531-533. doi:10.1046/j .1540-8175.2001.00531.x

Smith FM, West NH, Jones DR. 2000. The cardiovascular system. In Sturkie's avian physiology, 5th ed. (ed. Whittow GC), Chap. 9, pp. 141-231. Academic, San Diego.

Spach MS, Barr RC, Jewett PH. 1972. Spread of excitation from the atrium into thoracic veins in human beings and dogs. Am J Cardiol 30: 844-854. doi:10.1016/0002-9149 (72)90009-4

Steding G, Xu JW, Seidl W, Männer J, Xia H. 1990. Developmental aspects of the sinus valves and the sinus venosus septum of the right atrium in human embryos. Anat Embryol (Berl) 181: 469-475. doi:10.1007/ BF02433794

Stefanovic S, Barnett P, van Duijvenboden K, Weber D, Gessler M, Christoffels VM. 2014. GATA-dependent regulatory switches establish atrioventricular canal specificity during heart development. Nat Commun 5: 3680. doi:10.1038/ncomms4680

Stennard FA, Costa MW, Elliott DA, Rankin S, Haast SJ, Lai D, McDonald LP, Niederreither K, Dolle P, Bruneau BG, et al. 2003. Cardiac T-box factor Tbx20 directly interacts with Nkx2-5, GATA4, and GATA5 in regulation of gene expression in the developing heart. Dev Biol 262: 206224. doi:10.1016/S0012-1606(03)00385-3

Swett FH. 1923. The connecting systems of the reptile heart-alligator. Anat Rec 26: 129-140. doi:10.1002/ar .1090260207

Tattersall GJ. 2016. Reptile thermogenesis and the origins of endothermy. Zoology (Jena) 119: 403-405. doi:10.1016/j .zool.2016.03.001

Taylor EW, Leite CA, Sartori MR, Wang T, Abe AS, Crossley DA II. 2014. The phylogeny and ontogeny of autonomic control of the heart and cardiorespiratory interactions in vertebrates. J Exp Biol 217: 690-703. doi:10.1242/jeb .086199

Tessadori F, van Weerd JH, Burkhard SB, Verkerk AO, de Pater E, Boukens BJ, Vink A, Christoffels VM, Bakkers J. 2012. Identification and functional characterization of cardiac pacemaker cells in zebrafish. PLoS ONE 7: e47644. doi:10.1371/journal.pone.0047644

Tollis M, Hutchins ED, Kusumi K. 2014. Reptile genomes open the frontier for comparative analysis of amniote development and regeneration. Int J Dev Biol 58: 863871. doi:10.1387/ijdb.140316kk

Towbin JA, Jefferies JL. 2017. Cardiomyopathies due to left ventricular noncompaction, mitochondrial and storage diseases, and inborn errors of metabolism. Circ Res 121: 838-854. doi:10.1161/CIRCRESAHA.117.310987

Valentinuzzi ME, Hoff HE. 1972. The sinus venosus-atrial Wenckebach-Luciani phenomenon. J Electrocardiol 5: 114. doi:10.1016/S0022-0736(72)80057-8 van den Hoff MJ, Kruithof BP, Moorman AF, Markwald RR, Wessels A. 2001. Formation of myocardium after the initial development of the linear heart tube. Dev Biol 240: 61-76. doi:10.1006/dbio.2001.0449

van Eif VWW, Devalla HD, Boink GJJ, Christoffels VM. 2018. Transcriptional regulation of the cardiac conduction system. Nat Rev Cardiol 15: 617-630.

Van Mierop LHS, Kutsche LM. 1984. Comparative anatomy and embryology of the ventricles and arterial pole of the vertebrate heart. In Congenital heart disease: causes and processes (ed. Nora JJ, Takao A), pp. 459-479. Futura, New York.

Van Mierop LHS, Kutsche LM. 1985a. Development of the ventricular septum of the heart. Heart Vessels 1: 114-119. doi:10.1007/BF02066358

Van Mierop LHS, Kutsche LM. 1985b. Some aspects of comparative anatomy of the heart. In Cardiovascular shunts (ed. Johansen K, Burggren WW), pp. 38-56. Alfred Benzon Symposium 21, Munksgaard, Denmark.

van Soldt BJ, Metscher BD, Poelmann RE, Vervust B, Vonk FJ, Müller GB, Richardson MK. 2015. Heterochrony and early left-right asymmetry in the development of the cardiorespiratory system of snakes. PLOS ONE 10: e116416. doi:10.1371/journal.pone.0116416

Vedantham V, Galang G, Evangelista M, Deo RC, Srivastava D. 2015. RNA sequencing of mouse sinoatrial node reveals an upstream regulatory role for Islet-1 in cardiac pacemaker cells. Circ Res 116: 797-803. doi:10.1161/CIR CRESAHA.116.305913

Vonk FJ, Casewell NR, Henkel CV, Heimberg AM, Jansen HJ, McCleary RJ, Kerkkamp HM, Vos RA, Guerreiro I, Calvete JJ, et al. 2013. The king cobra genome reveals dynamic gene evolution and adaptation in the snake venom system. Proc Natl Acad Sci 110: 20651-20656. doi:10 $.1073 /$ pnas. 1314702110

Wang T, Altimiras J, Klein W, Axelsson M. 2003. Ventricular haemodynamics in Python molurus: separation of pulmonary and systemic pressures. J Exp Biol 206: 4241-4245. doi: $10.1242 /$ jeb.00681

Warren WC, Hillier LW, Marshall Graves JA, Birney E, Ponting CP, Grutzner F, Belov K, Miller W, Clarke L, Chinwalla AT, et al. 2008. Genome analysis of the platypus reveals unique signatures of evolution. Nature 453: 175183. doi: 10.1038 /nature 06936

Webb GJW. 1979. Comparative cardiac anatomy of the reptilia. III: The heart of crocodilians and an hypothesis on the completion of the interventricular septum of crocodilians and birds. J Morphol 161: 221-240. doi:10.1002/ jmor.1051610209

Webb G, Heatwole H, De Bavay J. 1971. Comparative cardiac anatomy of the reptilian. I: The chambers and septa of the varanid ventricle. J Morphol 134: 335-350. doi:10.1002/ jmor.1051340306

Werneburg I, Hugi J, Müller J, Sánchez-Villagra MR. 2009. Embryogenesis and ossification of Emydura subglobosa (testudines, pleurodira, chelidae) and patterns of turtle development. Dev Dyn 238: 2770-2786. doi:10.1002/ dvdy.22104

Wessels A, Vermeulen JL, Verbeek FJ, Virágh S, Kálman F, Lamers WH, Moorman AF. 1992. Spatial distribution of "tissue-specific" antigens in the developing human heart and skeletal muscle. III: An immunohisto- 
B. Jensen and V.M. Christoffels

chemical analysis of the distribution of the neural tissue antigen G1N2 in the embryonic heart; implications for the development of the atrioventricular conduction system. Anat Rec 232: 97-111. doi:10.1002/ar .1092320111

Wise PAD, Vickaryous MK, Russell AP. 2009. An embryonic staging table for in ovo development of Eublepharis macularius, the leopard gecko. Anat Rec 292: 1198-1212. doi:10.1002/ar.20945

Yamada M, Revelli JP, Eichele G, Barron M, Schwartz RJ. 2000. Expression of chick Tbx-2, Tbx-3, and Tbx-5 genes during early heart development: evidence for BMP2 induction of Tbx2. Dev Biol 228: 95-105. doi:10.1006/dbio .2000 .9927

Yelbuz TM, Waldo KL, Zhang X, Zdanowicz M, Parker J, Creazzo TL, Johnson GA, Kirby ML. 2003. Myocardial volume and organization are changed by failure of addition of secondary heart field myocardium to the cardiac outflow tract. Dev Dyn 228: 152-160. doi:10.1002/dvdy .10364
Yntema CL. 1968. A series of stages in the embryonic development of Chelydra serpentina. J Morphol 125: 219-251. doi:10.1002/jmor.1051250207

Young BA. 1994. Cartilago cordis in serpents. Anat Rec 240: 243-247. doi:10.1002/ar.1092400211

Zaffran S, Kelly RG, Meilhac SM, Buckingham ME, Brown NA. 2004. Right ventricular myocardium derives from the anterior heart field. Circ Res 95: 261-268. doi:10 .1161/01.RES.0000136815.73623.BE

Zehr DR. 1962. Stages in the normal development of the common garter snake, Thamnophis sirtalis sirtalis. Copeia 1962: 322-329. doi:10.2307/1440898

Zhang G, Li C, Li Q, Li B, Larkin DM, Lee C, Storz JF, Antunes A, Greenwold MJ, Meredith RW, et al. 2014. Comparative genomics reveals insights into avian genome evolution and adaptation. Science 346: 1311-1320. doi:10 $.1126 /$ science. 1251385

Zhao-Xian W, Ning-Zhen S, Wei-Ping M, Jie-Ping C, GongQing H. 1991. An analysis of electrocardiogram of Alligator sinensis. Comp Biochem Physiol 98A: 89-95. 


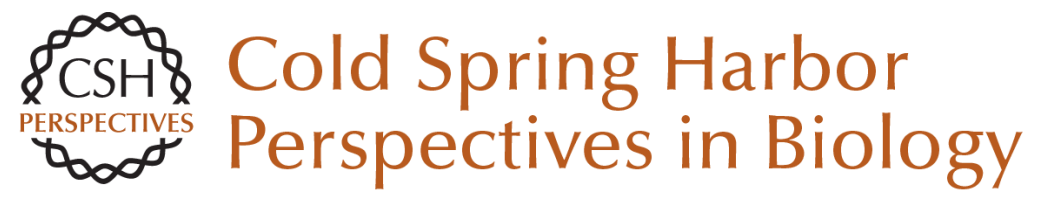

\section{Reptiles as a Model System to Study Heart Development}

Bjarke Jensen and Vincent M. Christoffels

Cold Spring Harb Perspect Biol 2020; doi: 10.1101/cshperspect.a037226 originally published online November 11, 2019

\section{Subject Collection Heart Development and Disease}

Epicardium in Heart Development

Yingxi Cao, Sierra Duca and Jingli Cao

Cardiac Neural Crest

Hiroyuki Yamagishi

The Endocardium and Heart Valves Bailey Dye and Joy Lincoln

Long Noncoding RNAs in Cardiac Development Michael Alexanian and Samir Ounzain

Genetic Basis of Human Congenital Heart Disease Shannon N. Nees and Wendy K. Chung

Cardiopharyngeal Progenitor Specification:

Multiple Roads to the Heart and Head Muscles Benjamin Swedlund and Fabienne Lescroart

Genetic and Epigenetic Control of Heart Development

Brynn N. Akerberg and William T. Pu

Formation and Growth of Cardiac Lymphatics during Embryonic Development, Heart Regeneration, and Disease

Dana Gancz, Gal Perlmoter and Karina Yaniv
In Vivo and In Vitro Genetic Models of Congenital Heart Disease

Uddalak Majumdar, Jun Yasuhara and Vidu Garg

Development of the Cardiac Conduction System

Samadrita Bhattacharyya and Nikhil V. Munshi

3D Anatomy of the Developing Heart:

Understanding Ventricular Septation

Timothy J. Mohun and Robert H. Anderson

Cardiac Morphogenesis: Specification of the

Four-Chambered Heart

Vincent Christoffels and Bjarke Jensen

The Chicken as a Model Organism to Study Heart

Development

Johannes G. Wittig and Andrea Münsterberg

The First Heartbeat--Origin of Cardiac Contractile

Activity

Richard C.V. Tyser and Shankar Srinivas

Xenopus: Experimental Access to Cardiovascular

Development, Regeneration Discovery, and

Cardiovascular Heart-Defect Modeling Stefan Hoppler and Frank L. Conlon

Reptiles as a Model System to Study Heart

Development

Bjarke Jensen and Vincent M. Christoffels

For additional articles in this collection, see http://cshperspectives.cshlp.org/cgi/collection/

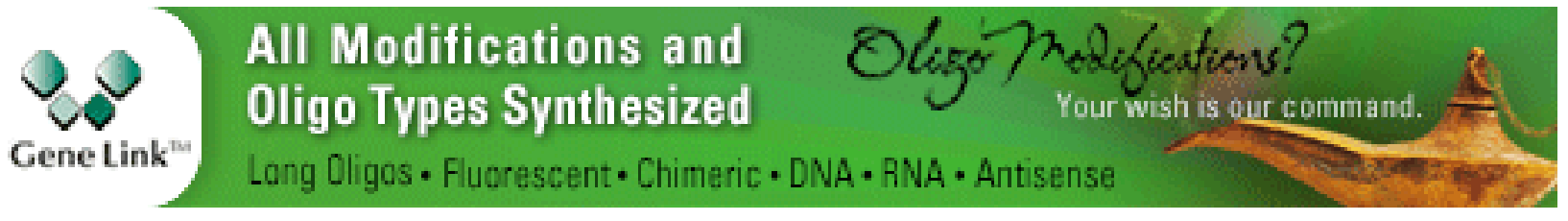

Copyright @ 2020 Cold Spring Harbor Laboratory Press; all rights reserved 